\title{
An unexpected new genus of panurgine bees (Hymenoptera, Andrenidae) from Europe discovered after phylogenomic analysis
}

\author{
Thomas J. Wood', Sébastien Patiny', Silas Bossert ${ }^{2,3}$ \\ I Laboratory of Zoology, University of Mons, Mons, Belgium 2 Department of Entomology, Washington State \\ University, Pullman, Washington, USA 3 Department of Entomology, National Museum of Natural History, \\ Smithsonian Institution, Washington, DC, USA \\ Corresponding author: Thomas J. Wood (thomasjames.wood@umons.ac.be)
}

Academic editor: Michael Ohl | Received 24 July 2021 | Accepted 19 January 2022 | Published 28 February 2022

http://zoobank.org/EBFE14EO-B8CF-40DB-A143-9595D77F1D8C

Citation: Wood TJ, Patiny S, Bossert S (2022) An unexpected new genus of panurgine bees (Hymenoptera, Andrenidae) from Europe discovered after phylogenomic analysis. Journal of Hymenoptera Research 89: 183-210. https://doi.org/10.3897/jhr.89.72083

\begin{abstract}
Establishing a higher classification of bees based on morphology alone can fail to capture evolutionary relationships when morphological characters either vary very little between distantly related groups, or conversely vary greatly between closely related species. This problem is well represented in the subfamily Panurginae, for which a recent global revision based on phylogenomic data unexpectedly revealed that two Old World species previously placed in Camptopoeum Spinola and Flavipanurgus Warncke, are in fact most closely related to each other, and together form a sister group relationship to the remaining Flavipanurgus and Panurgus Panzer combined. To rectify this situation, we here establish an expanded phylogenomic data set of Old World Panurgini and re-assess generic and subgeneric concepts for the tribe. To solve the paraphyly of Camptopoeum and Flavipanurgus, we establish the new genus Halopanurgus gen. nov. containing the species $H$. baldocki (Wood \& Cross), comb. nov. and $H$. fuzetus (Patiny), comb. nov., both of which are restricted to coastal sands, saltmarshes, and inland saline lagoons in the extreme south of Portugal and south-west of Spain. Re-evaluation of four recently used subgenera in Panurgus strongly supports a simplified classification of two subgenera; Pachycephalopanurgus Patiny, stat. rev. including Micropanurgus Patiny syn. nov., and Panurgus s. str. including Euryvalvus Patiny. Pachycephalopanurgus species seem to be oligoleges of Asteroideae (Asteraceae), whereas Panurgus s. str. may be oligoleges of Cichorieae (Asteraceae). Our findings reinforce the challenges of establishing a phylogenetically sound classification of Panurginae using morphology alone and illustrate that even in well-studied regions like Europe unrecognised genera can persist in underexplored corners of the continent.
\end{abstract}

Copyright Thomas J. Wood et al. This is an open access article distributed under the terms of the Creative Commons Attribution License (CC BY 4.0), which permits unrestricted use, distribution, and reproduction in any medium, provided the original author and source are credited. 


\section{Keywords}

Asteraceae, halophile, Iberian endemic species, solitary bees, taxonomy

\section{Introduction}

The bee fauna of Europe boasts the longest history of study, and as such has a relatively stable system of taxonomic classification. Depending on taxonomic interpretation, 73 bee genera are known from Europe (Rasmont et al. 2017) when taking a broad approach to Eucera (including Cubitalia, Synhalonia, Tetralonia, and Tetraloniella; Dorchin et al. 2018) and considering Halictus to consist of Halictus s. str. and its sister group Seladonia, the latter including Vestitohalictus (Danforth et al. 1999). As a measure of this stability, only six valid genera have been described for the European bee fauna since 1955, specifically the species-poor lineages Clavipanurgus, Flavipanurgus, and Simpanurgus (Warncke 1972), Hofferia and Stenoheriades (Tkalců 1984), and Chiasmognathus (Engel 2006) (Fig. 1). In contrast, some 20 genera have been described for the broader West Palaearctic region during this time.

Key to maintaining stable bee genera for the future is the use of large-scale molecular revisions to re-evaluate lineages where generic boundaries are ambiguous due to morphological intergradation (Dorchin et al. 2018), or conversely where a great deal of morphological variation has led to a proliferation of described genera that are paraphyletic (Litman et al. 2016). Integrating phylogenomic datasets with traditional morphological study allows the reciprocal illumination of morphological features in light of molecular evidence, and greatly facilitates the systematic identification of synapomorphies and homologous characters for diagnostic purposes (Bossert et al. 2020). The classification of the Panurginae presents aspects of these problems, and delineating the phylogenetic relationships between the different genera has proved challenging for several decades. This has led to numerous tribal classification schemes, as well as disagreement as to what constitutes a genus in some cases (Patiny 2001; Ascher 2004; Engel 2005; Michener 2007; Ascher and Engel 2017). For example, Engel (2005) places the Melitturgini sensu Patiny (1999a) within the Panurgini and distinct from the Meliturgulini, whereas Michener (2007) places both together in Melitturgini, and Michener (2007) takes a broad approach to Panurgus, including both Flavipanurgus and Simpanurgus as subgenera. Treatment of the tribe Panurgini has been particularly problematic, with some interpretations including a limited number of Old World taxa (Patiny 2001), or conversely including all Old World and even some New World taxa (Ascher 2004).

The lack of resolution from morphological analyses has recently been addressed through a phylogenomic approach using Ultraconserved Elements (UCEs; Bossert et al. 2022). An important finding of that study is that the Old World Panurginae are not a monophyletic group. The tribe Melitturgini, comprising only Camptopoeum and Melitturga, is well-separated from all other Old World genera which can be placed in 


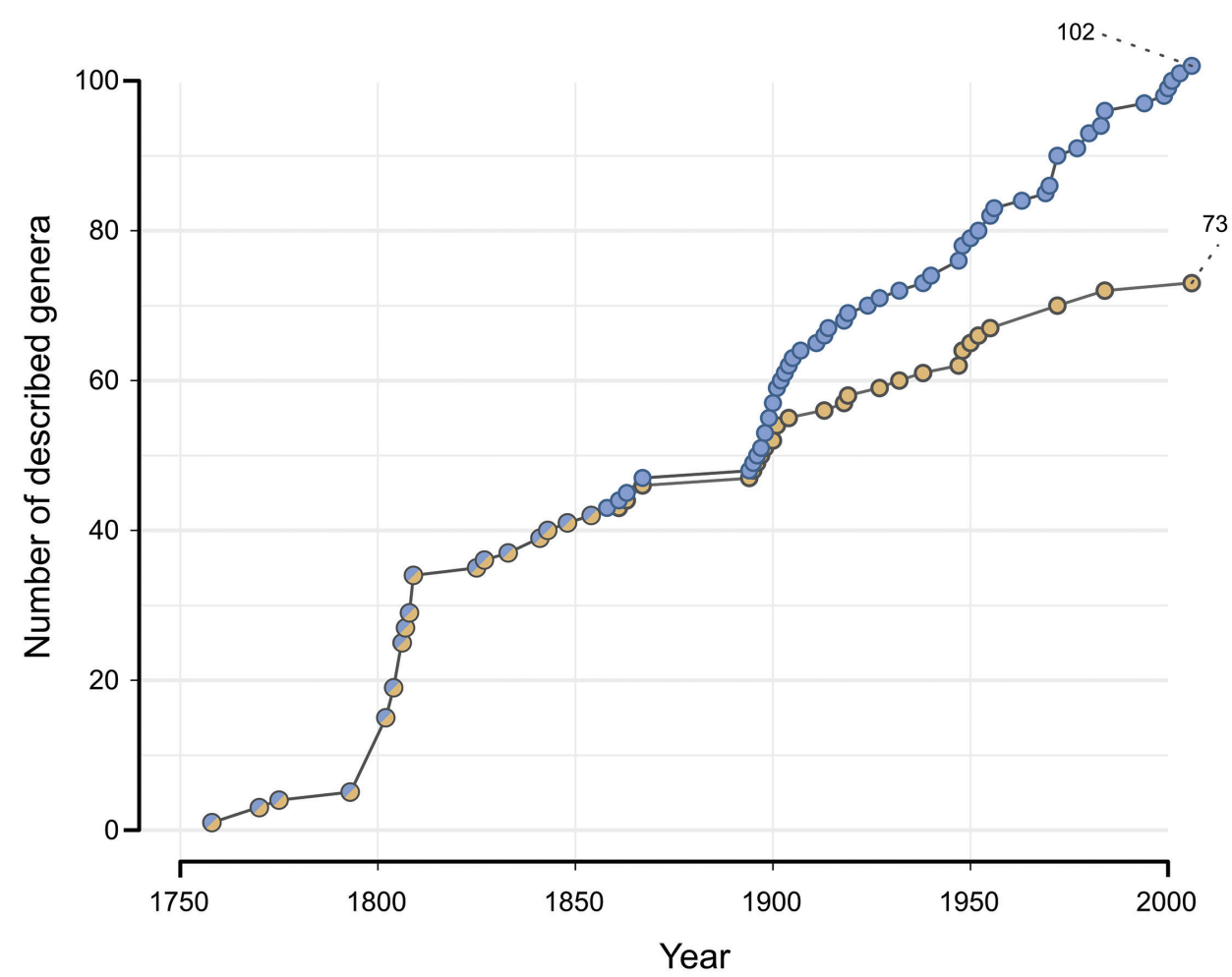

Figure I. Cumulative number of valid bee genera by year of description for Europe (as defined by Rasmont et al. 2017) (yellow dots) and the wider West Palaearctic region (blue dots). The recognition of genera follows Rasmont et al. (2017) with modifications as defined in the introduction.

a single large tribe, the Panurgini. Sister group to the Panurgini is the endemic North American lineage Perditini, and both these lineages are sister group to Melitturgini: Melitturgini + (Perditini + Panurgini). The Melitturgini likely diverged from the lineage that gave rise to the present-day Panurgini and Perditini 46.1 million years ago (95\% highest posterior density 36.8-56.1 mya, Bossert et al. 2022), shortly after their most recent common ancestor (MRCA) colonised the Palaearctic. Both Panurgini and Perditini descend from this MRCA, indicating that Panurginae only geodispersed to the Old World a single time (Bossert et al. 2022). Another surprising finding is that one species described as Camptopoeum (Camptopoeum) baldocki Wood \& Cross, 2017 on the basis of its seemingly distinctively long glossa (Wood and Cross 2017, the glossa itself being elongate, not possessing the elongate labial palp morphology used in the division between long-tongued and short-tongued bees, see Michener (2007)) is not actually part of the lineage forming Camptopeum and Melitturga (the Melitturgini), but instead is more closely related to the genera Flavipanurgus and Panurgus. Specifically, this species forms a sister group relationship with Flavipanurgus fuzetus Patiny, 1999, which has a short glossa consistent with other members of this genus (Patiny 1999b), but its placement together with C. baldocki renders Flavipanurgus paraphyletic. 
Given this paraphyly, the main objectives of the current work are therefore to reassess the diagnosability of Flavipanurgus and Panurgus, re-evaluate the current usage of subgenera for Panurgus, and identify morphological criteria to allow for recognition of these different lineages. Considering morphological, molecular, and ecological aspects, we describe the new genus Halopanurgus gen. nov. to ensure that all genera are strictly monophyletic. We also take the opportunity to discuss the relationships between the different West Mediterranean genera of Panurgini, as this region is clearly a particular centre of their Old World diversity, and lastly we propose a simplified subgeneric classification for the genus Panurgus.

\section{Methodology}

\section{Molecular methods}

To better understand the phylogenetic relationships of Panurgus and its currently used subgenera, as well as of Flavipanurgus, and Halopanurgus gen. nov., we assembled a taxon-dense sampling of Old World Panurginae. We obtained DNA sequence data from a recently published phylogeny of Andrenidae (Bossert et al. 2022) and enriched these data with additional samples for our group of interest. Specifically, we included all $\mathrm{Pa}$ nurgus, Flavipanurgus and "Camptopoeum baldocki" from Bossert et al. (2022), as well as three representatives for both of the closely related tribes Melitturgini and Perditini. Additionally, we included one representative for each of the three clades of Panurgini outside of our group of interest that were identified in Bossert et al. (2022), and chose Neffapis longilingua as our most distant outgroup. We combined this publicly available UCE sequence data with nine newly analysed samples for Panurgus and Flavipanurgus. We generated new sequence data for eight species of Panurgus, including four new samples of the previously underrepresented subgenus Pachycephalopanurgus. This ensures the representation of six out of seven described species of this subgenus sensu Patiny (1999c), both known species of the subgenus Euryvalvus, one of the three species of the subgenus Micropanurgus sensu Patiny (2002), and 10 out of the 22 species of Panurgus s. str. Lastly, we included UCE sequence data of Flavipanurgus venustus (Erichson, 1835), ensuring representation of five out of the seven currently recognised species of Flavipanurgus. Our taxon sampling totals 35 species. NCBI SRA accession numbers, collection localities and voucher depositories can be found in Table 1 .

The molecular lab procedures for UCE sequencing of the nine newly analysed samples are detailed in Bossert et al. (2022), including library preparation, enrichment, and sequencing, since the newly presented data was generated jointly with this previous dataset. All newly analysed samples were enriched with the enhanced principal Hymenoptera bait set (Branstetter et al. 2017). Bioinformatic processing of these data follows the workflow detailed in Bossert et al. (2022), including the same programs and parameters for demultiplexing and sequence assembly (using SPAdes v. 3.13; Bankevich et al. 2012). After combining the new sequence data with the previously 
Table I. The scientific names of the included species with their collection localities and voucher depositories. NCBI SRA IDs marked with an asterisk $\left({ }^{*}\right)$ indicate samples that are newly published. Most voucher specimens are labelled with a green coloured label which carries the voucher code. UCE assemblies of the newly generated sequence are available on the FighShare repository associated with this article (10.6084/m9.figshare.15033552). Acronyms for the collection depositories: Cornell Univ. Insect Collection (CUIC); Collection Silas Bossert (CSB); University of Mons-Hainaut, Mons, Belgium (UMH); Collection Thomas Wood, Mons, Belgium (CTW).

\begin{tabular}{|c|c|c|c|c|c|}
\hline Taxon & Locality & $\begin{array}{l}\text { Voucher } \\
\text { depository }\end{array}$ & Collector / Identifier & $\begin{array}{l}\text { Voucher } \\
\text { Code }\end{array}$ & SRA \\
\hline $\begin{array}{l}\text { Camptopoeum (Camp- } \\
\text { topoeum) frontale }\end{array}$ & Turkey: Agr I, Gögoglu & UMH & P. Rasmont / D. Michez & BND-1981 & SRR16232743 \\
\hline $\begin{array}{l}\text { Camptopoeum (Camp- } \\
\text { topoeum) negevense }\end{array}$ & $\begin{array}{l}\text { Israel: S Negev, } 13 \text { km } \\
\text { N Shizzafon Jct. }\end{array}$ & $\mathrm{n} / \mathrm{a}$ & from Ascher (2004) & Camp 41 & SRR16232742 \\
\hline Clavipanurgus desertus & Morocco: S. Anezal & CSB & $\begin{array}{l}\text { Michez \& Patiny / } \\
\text { Michez \& Patiny }\end{array}$ & BND-1982 & SRR16232741 \\
\hline Flavipanurgus flavus & $\begin{array}{c}\text { Portugal: Algarve, } \\
\text { Aljezur }\end{array}$ & CTW & T. J. Wood / T. J. Wood & BND-2119 & SRR16232720 \\
\hline Flavipanurgus ibericus & $\begin{array}{l}\text { Portugal: Alentejo, } \\
\text { Mértola }\end{array}$ & CSB & I. C. Cross / T. J. Wood & BND-2117 & SRR16232718 \\
\hline $\begin{array}{l}\text { Flavipanurgus kastil- } \\
\text { iensis }\end{array}$ & $\begin{array}{c}\text { Portugal: Pardelhas, } \\
\text { Vila Real }\end{array}$ & CTW & T. J. Wood / T. J. Wood & BND-2118 & SRR16232717 \\
\hline Flavipanurgus venustus & Spain: Doñana & $\mathrm{UMH}$ & F.P. Molina / D. Michez & BND-1926 & SRR17049175 \\
\hline Halopanurgus baldocki & $\begin{array}{l}\text { Portugal: Algarve, } \\
\text { Cacela Velha }\end{array}$ & CSB & T. J. Wood / T. J. Wood & BND-1923 & SRR16232744 \\
\hline Halopanurgus fuzetus & $\begin{array}{l}\text { Portugal: Algarve, } \\
\text { Cacela Velha }\end{array}$ & CTW & T. J. Wood / T. J. Wood & BND-2120 & SRR16232719 \\
\hline $\begin{array}{l}\text { Macrotera (Macroter- } \\
\text { ella) mortuaria }\end{array}$ & $\begin{array}{l}\text { USA: NV, Clark Co., } \\
\text { Sacatone Wash }\end{array}$ & BBSL & $\begin{array}{l}\text { T. Griswold / T. Gris- } \\
\text { wold }\end{array}$ & BND-2005 & SRR16232673 \\
\hline $\begin{array}{l}\text { Melitturga (Melitturga) } \\
\text { clavicornis }\end{array}$ & $\begin{array}{c}\text { France: Hérault, Causse } \\
\text { de la Selle }\end{array}$ & $\mathrm{n} / \mathrm{a}$ & from Ascher (2004) & Mecl 73 & SRR16232665 \\
\hline $\begin{array}{l}\text { Meliturgula (Melitur- } \\
\text { gula) scriptifrons }\end{array}$ & $\begin{array}{l}\text { South Africa: Limpopo, } \\
77 \mathrm{~km} \mathrm{~S} \text { Ellisras }\end{array}$ & CUIC & $\begin{array}{l}\text { B.N.D. / B.N.D. } \\
\text { \#CUIC code: 04-22 }\end{array}$ & BND-1037 & SRR16232644 \\
\hline Neffapis longilingua & $\begin{array}{l}\text { Chile: Coquimbo Re- } \\
\text { gion, Vicuńa }\end{array}$ & RPSP & L.Packer / L. Packer & BBX-694 & SRR16232638 \\
\hline $\begin{array}{l}\text { Panurgus (Pachycepha- } \\
\text { lopanurgus) acutus }\end{array}$ & $\begin{array}{l}\text { Morocco/SW: } 15 \mathrm{~km} \\
\text { NE Agadir }\end{array}$ & CSB & $\begin{array}{c}\text { C. Schmid-Egger / S. } \\
\text { Patiny }\end{array}$ & BND-1952 & SRR16232763 \\
\hline $\begin{array}{l}\text { Panurgus (Pachycepha- } \\
\text { lopanurgus) calceatus }\end{array}$ & $\begin{array}{l}\text { Morocco: Errachidia- } \\
\text { Erfoud }\end{array}$ & UMH & $\begin{array}{l}\text { Michez \& Patiny / } \\
\text { Michez \& Patiny }\end{array}$ & BND-1931 & SRR17049183 \\
\hline $\begin{array}{l}\text { Panurgus (Pachycepha- } \\
\text { lopanurgus) canescens }\end{array}$ & Spain: Sierra Nevada & $\mathrm{UMH}$ & $\begin{array}{c}\text { J. Ortiz-Sánchez / S. } \\
\text { Patiny }\end{array}$ & BND-1932 & SSR17049182 \\
\hline $\begin{array}{l}\text { Panurgus (Pachycepha- } \\
\text { lopanurgus) convergens }\end{array}$ & Morocco: Anezal & UMH & $\begin{array}{l}\text { Michez \& Patiny / } \\
\text { Michez \& Patiny }\end{array}$ & BND-1933 & SSR17049181 \\
\hline $\begin{array}{l}\text { Panurgus (Pachycepha- } \\
\text { lopanurgus) farinosus }\end{array}$ & Morocco: Marrakech & UMH & $\begin{array}{l}\text { Michez \& Patiny / } \\
\text { Michez \& Patiny }\end{array}$ & BND-1936 & SSR17049180 \\
\hline $\begin{array}{l}\text { Panurgus (Pachycepha- } \\
\text { lopanurgus) nigriscopus }\end{array}$ & $\begin{array}{l}\text { Morocco: Drâa-Tafila- } \\
\text { let, Ouarzazate }\end{array}$ & CSB & $\begin{array}{l}\text { Michez \& Patiny / } \\
\text { Michez \& Patiny }\end{array}$ & BND-1938 & SRR16232758 \\
\hline $\begin{array}{l}\text { Panurgus (Pachycepha- } \\
\text { lopanurgus) rungsii }\end{array}$ & $\begin{array}{l}\text { Morocco: Drâa-Tafila- } \\
\text { let, Ouarzazate }\end{array}$ & CSB & $\begin{array}{l}\text { Michez \& Patiny / } \\
\text { Michez \& Patiny }\end{array}$ & BND-1943 & SRR16232737 \\
\hline $\begin{array}{l}\text { Panurgus (Panurgus) } \\
\text { avarus }\end{array}$ & $\begin{array}{l}\text { Morocco: Drâa-Tafila- } \\
\text { let, Ouarzazate }\end{array}$ & CSB & $\begin{array}{l}\text { Michez \& Patiny / } \\
\text { Michez \& Patiny }\end{array}$ & BND-1929 & SRR16232762 \\
\hline $\begin{array}{l}\text { Panurgus (Panurgus) } \\
\text { banksianus }\end{array}$ & $\begin{array}{l}\text { France: Pyrénées-Or. } \\
\text { Eyne, cabane météo }\end{array}$ & UMH & D. Michez / D. Michez & BND-1930 & SRR16232761 \\
\hline $\begin{array}{l}\text { Panurgus (Panurgus) } \\
\text { calcaratus }\end{array}$ & $\begin{array}{l}\text { Spain: Province of } \\
\text { Almería }\end{array}$ & UMH & $\begin{array}{c}\text { J. Ortiz-Sánchez / S. } \\
\text { Patiny }\end{array}$ & BND-514 & SSR17049179 \\
\hline
\end{tabular}




\begin{tabular}{|c|c|c|c|c|c|}
\hline Taxon & Locality & $\begin{array}{c}\text { Voucher } \\
\text { depository }\end{array}$ & Collector / Identifier & $\begin{array}{l}\text { Voucher } \\
\text { Code }\end{array}$ & SRA \\
\hline $\begin{array}{l}\text { Panurgus (Panurgus) } \\
\text { cephalotes }\end{array}$ & $\begin{array}{l}\text { Portugal: Trás-os-mon- } \\
\text { tes, Espinhosela }\end{array}$ & CTW & T. J. Wood / T. J. Wood & BND-1985 & SSR17049178 \\
\hline $\begin{array}{l}\text { Panurgus (Panurgus) } \\
\text { dentatus }\end{array}$ & $\begin{array}{l}\text { Morocco: Drâa-Tafila- } \\
\text { let, Imider }\end{array}$ & $\mathrm{UMH}$ & $\begin{array}{l}\text { Michez \& Patiny / } \\
\text { Michez \& Patiny }\end{array}$ & BND-1934 & SSR17049177 \\
\hline $\begin{array}{l}\text { Panurgus (Panurgus) } \\
\text { dentipes }\end{array}$ & $\begin{array}{l}\text { France: Marseilles, } \\
\text { Campus Luminy }\end{array}$ & $\mathrm{UMH}$ & D. Michez / D. Michez & BND-1935 & SRR16232760 \\
\hline $\begin{array}{l}\text { Panurgus (Panurgus) } \\
\text { maroccanus }\end{array}$ & $\begin{array}{l}\text { Morocco: Drâa-Tafila- } \\
\text { let, Ouarzazate }\end{array}$ & CSB & $\begin{array}{l}\text { Michez \& Patiny / } \\
\text { Michez \& Patiny }\end{array}$ & BND-1937 & SRR16232759 \\
\hline $\begin{array}{l}\text { Panurgus (Panurgus) } \\
\text { niloticus }\end{array}$ & $\begin{array}{l}\text { Morocco: Drâa-Tafila- } \\
\text { let, Ouarzazate }\end{array}$ & UMH & $\begin{array}{l}\text { Michez \& Patiny / } \\
\text { Michez \& Patiny }\end{array}$ & BND-1939 & SRR16232757 \\
\hline $\begin{array}{l}\text { Panurgus (Panurgus) } \\
\text { perezi }\end{array}$ & $\begin{array}{l}\text { Portugal: Trás-os-mon- } \\
\text { tes, Vila Real }\end{array}$ & CTW & T. J. Wood / T. J. Wood & BND-1940 & SSR17049176 \\
\hline $\begin{array}{l}\text { Panurgus (Panurgus) } \\
\text { pici }\end{array}$ & $\begin{array}{l}\text { Morocco: Drâa-Tafila- } \\
\text { let, Ouarzazate }\end{array}$ & UMH & $\begin{array}{l}\text { Michez \& Patiny / } \\
\text { Michez \& Patiny }\end{array}$ & BND-1941 & SRR16232740 \\
\hline $\begin{array}{l}\text { Panurgus (Panurgus) } \\
\text { pyropygus }\end{array}$ & $\begin{array}{l}\text { Morocco: Drâa-Tafila- } \\
\text { let, Ouarzazate }\end{array}$ & CSB & $\begin{array}{l}\text { Michez \& Patiny / } \\
\text { Michez \& Patiny }\end{array}$ & BND-1942 & SRR16232738 \\
\hline $\begin{array}{l}\text { Panurgus (Panurgus) } \\
\text { siculus }\end{array}$ & $\begin{array}{l}\text { Malta: Southeastern } \\
\text { District, Ghaxaq }\end{array}$ & $\mathrm{UMH}$ & $\begin{array}{c}\text { Michez \& Balzan / D. } \\
\text { Michez }\end{array}$ & BND-1944 & SRR16232736 \\
\hline $\begin{array}{l}\text { Perdita (Hesperoper- } \\
\text { dita) trisignata }\end{array}$ & USA: California & $\mathrm{n} / \mathrm{a}$ & from Ascher (2004) & $\mathrm{PeHe} 77$ & SRR16232659 \\
\hline $\begin{array}{l}\text { Perdita (Pygoperdita) } \\
\text { californica }\end{array}$ & $\begin{array}{l}\text { USA: CA, Contra Costa } \\
\text { Co., Donner Cyn. }\end{array}$ & $\mathrm{n} / \mathrm{a}$ & B. Danforth / n. a. & BND-518 & SRR16232713 \\
\hline $\begin{array}{l}\text { Plesiopanurgus (Zizo- } \\
\text { panurgus) zizus }\end{array}$ & $\begin{array}{l}\text { Morocco: Drâa-Tafila- } \\
\text { let, Ouarzazate }\end{array}$ & CSB & $\begin{array}{l}\text { Michez \& Patiny / } \\
\text { Michez \& Patiny }\end{array}$ & BND-1945 & SRR16232657 \\
\hline
\end{tabular}

published assemblies, we used the Phyluce pipeline (v. 1.7.1; Faircloth 2016) to search the assemblies for UCE sequences (with min-coverage and min-identity parameters of 80), aligned the data with MAFFT and the L-INS-i mode (v. 7.130b; Katoh and Standley 2013), and trimmed the alignments with Gblocks (Castresana 2000) and adjusted parameters ( $-\mathrm{b} 10.5,-\mathrm{b} 20.5625,-\mathrm{b} 310,-\mathrm{b} 45)$. We additionally processed the alignments with Spruceup (Borowiec 2019) and generated a concatenated sequence matrix of $80 \%$, meaning that every individual UCE locus is represented by at least 28 taxa.

We estimated phylogenetic relationships with the maximum likelihood implementation IQ-Tree (v. 2.1.3; Minh et al. 2020). Substitution models were assigned after combining partitions of similar substitution patterns using the greedy search strategy (Lanfear et al. 2012). To ease the computational burden, we used the relaxed hierarchical clustering method (Lanfear et al. 2014) at 50\% (- rcluster 50). Model selection was carried out with Modelfinder (Kalyaanamoorthy et al. 2017) and support was assessed with 1,000 ultrafast bootstrap approximations (UFBoot2; Hoang et al. 2018).

Newly generated SPAdes assemblies, the concatenated alignment, tree files, and the input files used to generate the phylogeny are deposited in a FigShare online repository associated with this article $(10.6084 / \mathrm{m} 9$.figshare.15033552). Unprocessed Illumina sequence reads generated for this study are deposited in the NCBI Sequence Read Archive (SRA) under BioProject PRJNA783908 or under the individual identifiers listed in Table 1. 


\section{Pollen analysis}

Pollen was removed from Panurgus species whose pollen preferences have not previously been quantified to assess their pollen preferences following the methodology of Wood \& Roberts (2018). The size of pollen loads on individual bees was estimated, ranging from a full load to a one-eighth load. Pollen grains were removed from the scopa using an entomological pin and transferred to a drop of water on a microscope slide. Grains were left to absorb water for a few minutes and then the slides were gently heated to allow evaporation. Molten glycerine jelly stained with fuchsin was added, and the slide was sealed with a coverslip. The percentage of the load composed of different plant taxa was estimated along three randomly selected lines across the cover slip at a magnification of $\times 400$. The percentage of the load was estimated by the relative area of the slide occupied by each plant species, rather than the absolute number of grains. Pollen species representing $<2 \%$ of the load were excluded from further analysis because their presence might have arisen from contamination. The percentages of pollen collected were multiplied by the overall size of each load to give a final weighting i.e., a taxon comprising $50 \%$ of a $3 / 4$ full pollen load would receive a weight of 37.5 , whereas a taxon with $100 \%$ of a full $(1 / 1)$ pollen load would receive a weight of 100.0. Pollen loads were identified to the lowest taxonomic level possible using a reference collection assembled during the project, in most cases to subfamily. Host range (dietary specialisation) was characterised following the criteria of Müller and Kuhlmann (2008).

\section{Terminology and imaging}

Morphological terminology follows Michener (2007). Michener (2007) was also used as the baseline for taxonomic changes to the subgeneric classification of Panurgus, and generic and subgeneric synonymy was adapted from this work. Photographs were taken using an Olympus E-M1 Mark II with a $60 \mathrm{~mm}$ macro lens. Close-ups were taken with the addition of a Mitutoyo M Plan Apo 10x infinity corrected objective lens in combination with an Olympus M.Zuiko $2 \times$ teleconverter lens, a $10 \mathrm{~mm}$ Kenko DG extension tube, and a Meike MK-P-AF3B $10 \mathrm{~mm}$ extension tube. Photographs were stacked using Zerene Stacker 1.04 (Zerene Systems, USA) and plates were prepared in GNU Image Manipulation Program (GIMP) 2.10. Post-processing of some images was made in Photoshop Elements (Adobe Systems, USA) to improve lighting to highlight specific characters.

\section{Results}

\section{Molecular phylogeny}

Combining the newly presented UCE sequences of Panurgus with previously published data led to a concatenated sequence alignment of 1,289,627 DNA nucleotides and 35 species. The maximum likelihood analysis with IQ-Tree produced a highly supported 
phylogeny that resolves the phylogenetic relationships among the examined genera and specifically of the subgenera of Panurgus (Fig. 2). Only the single node involving Panurgus dentatus Friese, 1901, P. pici Pérez, 1895, P. avarus Warncke, 1972, and P. niloticus Warncke, 1972 received a comparatively low bootstrap value of 53 . This means that while this particular placement should be interpreted cautiously, the remaining phylogenetic relationships were resolved with high confidence. The phylogeny is congruent with the previous ML and Bayesian phylogenies of Panurgini in Bossert et al. (2022): even though the present tree includes an additional eight taxa of Panurgus, it is otherwise topologically identical to these previous estimates. While similar phylogenies can be expected given the shared data between these two studies, the present nucleotide matrix is nearly twice as long as the more strictly trimmed alignment of Bossert et al. (2022; 595,217 nucleotides).

Our phylogeny shows that Flavipanurgus in its previous sense, i.e., including "Flavipanurgus" fuzetus, is not a monophyletic group (Fig. 2). This species is not more closely related to the remaining Flavipanurgus than to Panurgus. Instead, it forms a sister group relationship with "Camptopoeum" baldocki, a lineage previously thought to be part of the genus Camptopoeum (Wood and Cross 2017). Recent phylogenomic analyses of the higher-level relationships of Panurginae found Camptopoeum to be most closely related to Melitturga, and hence not part of the clade investigated in the present study (Bossert et al. 2022). This means that "Camptopoeum" baldocki renders Camptopoeum paraphyletic, requiring taxonomic change. To rectify the paraphyly of both Camptopoeum and Flavipanurgus, we establish the new genus Halopanurgus gen. nov. that unites both "Flavipanurgus" fuzetus and "Camptopoeum" baldocki into one genus and ensures monophyly of both Flavipanurgus and Camptopoeum.

The presented molecular-phylogenetic relationships allow us to illuminate the subgeneric concepts of Panurgus with the four subgenera Euryvalvus, Micropanurgus, Panurgus, and Pachycephalopanurgus as established by Patiny (1999c). We found the subgenus Euryvalvus with its two species $P$. banksianus and $P$. pyropygus to be nested within the largest subgenus Panurgus s. str., and the included representative of the morphologically derived Micropanurgus renders Pachycephalopanurgus paraphyletic. Re-evaluating the morphological characters of these lineages in light of phylogeny, particularly of the highly informative male genitalia, we found that a simplified classification of Panurgus with an expanded Panurgus s. str. (including Euryvalvus) and Pachycephalopanurgus (including Micropanurgus) is most appropriate (1) to maintain readily diagnosable subgenera, (2) to ensure monophyletic groupings, and (3) to reflect the antiquity of the respective lineages. The taxonomic changes are formalised below.

\section{Taxonomy}

Tribe Panurgini Leach, 1815

Halopanurgus Wood, Patiny \& Bossert, gen. nov. http://zoobank.org/D0AEA39D-BF99-406A-A439-38721C79E825

Type species. Camptopoeum baldocki Wood \& Cross, 2017 


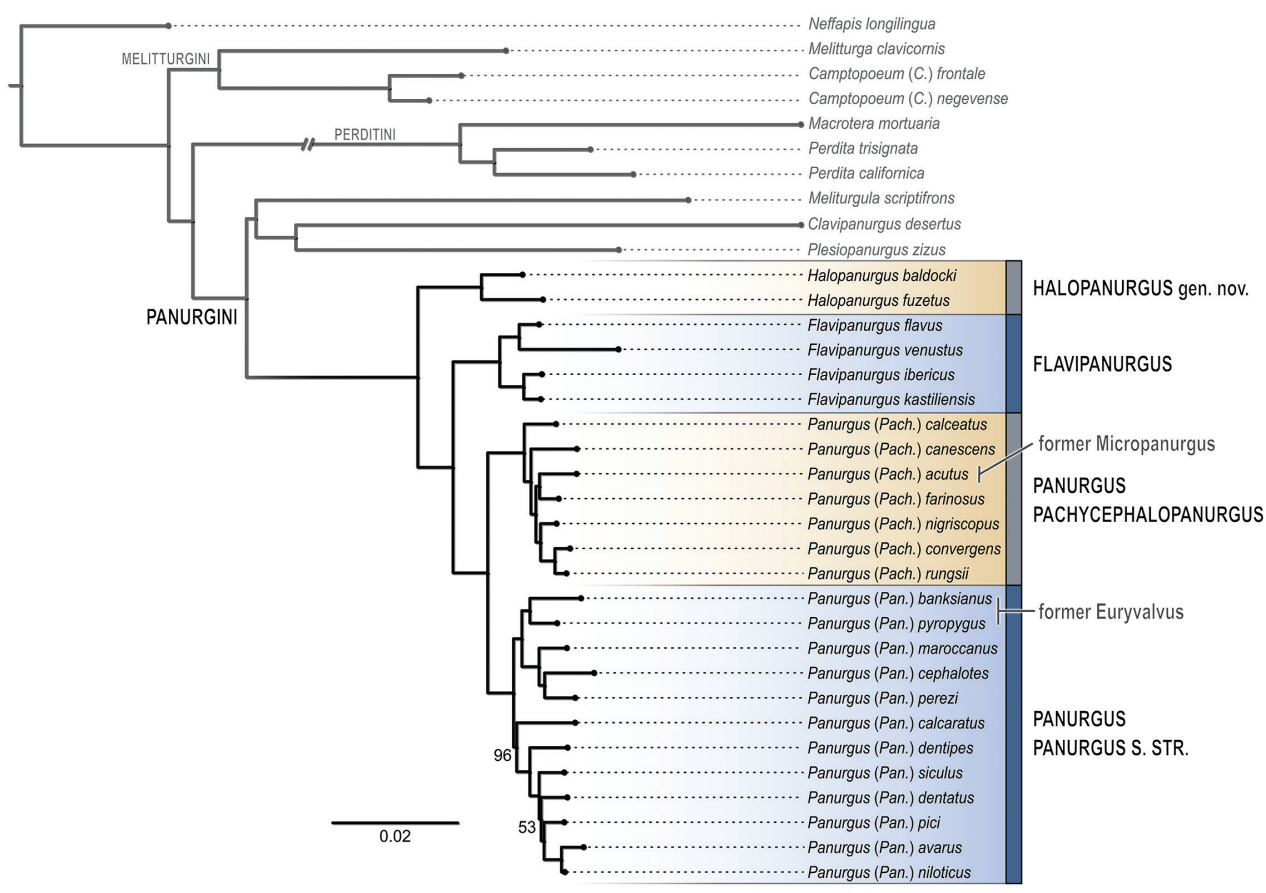

Figure 2. Maximum Likelihood phylogeny of Panurgus, Flavipanurgus, and the newly described genus Halopanurgus gen. nov., based on 2,055 ultraconserved elements. Taxonomic names reflect the nomenclatural changes proposed in this study. Node support corresponds to 100 ultrafast bootstrap support values unless indicated otherwise.

Diagnosis. Halopanurgus can be recognised as a panurgine because of its black body with yellow maculations on the head, mesosoma, and metasoma, its small size (4-5 mm), its two submarginal cells, apically truncate marginal cell, poorly developed femoral scopa, two subantennal sutures, and weak facial fovea, these shining, hairless. It is best diagnosed with reference to other similar small, yellow-marked genera with two submarginal cells, as broad characters like those used for tribal classification by Michener (2007) are not universally applicable and are not supported by the new phylogeny (Bossert et al. 2022).

Halopanurgus can be confused with Camptopoeum because of the similar structure of the male S7 and genital capsule. Camptopoeum has S7 as broad as long or slightly longer than broad, almost parallel sided, and with a broad apical notch (Fig. 14), and the genital capsule is parallel sided, with simple gonostyli and penis valves (Figs 6-7). In Halopanurgus S7 is broader, but still apically notched (Fig. 12) and the gonocoxae are produced into strong triangular points apically (Figs 3-4). In Camptopoeum no such points are present; the inner margin of the gonocoxae is clearly smooth and inwardly curved (in both subgenera Camptopoeum s. str. and Epimethea, Figs 6-7).

Separation from Flavipanurgus is simple in the male sex, as Flavipanurgus has S7 clearly broader than long, and deeply excavated apicomedially (Figs 15-16). The genital capsule is also different with the gonocoxae lacking apical points and the gonostyli 


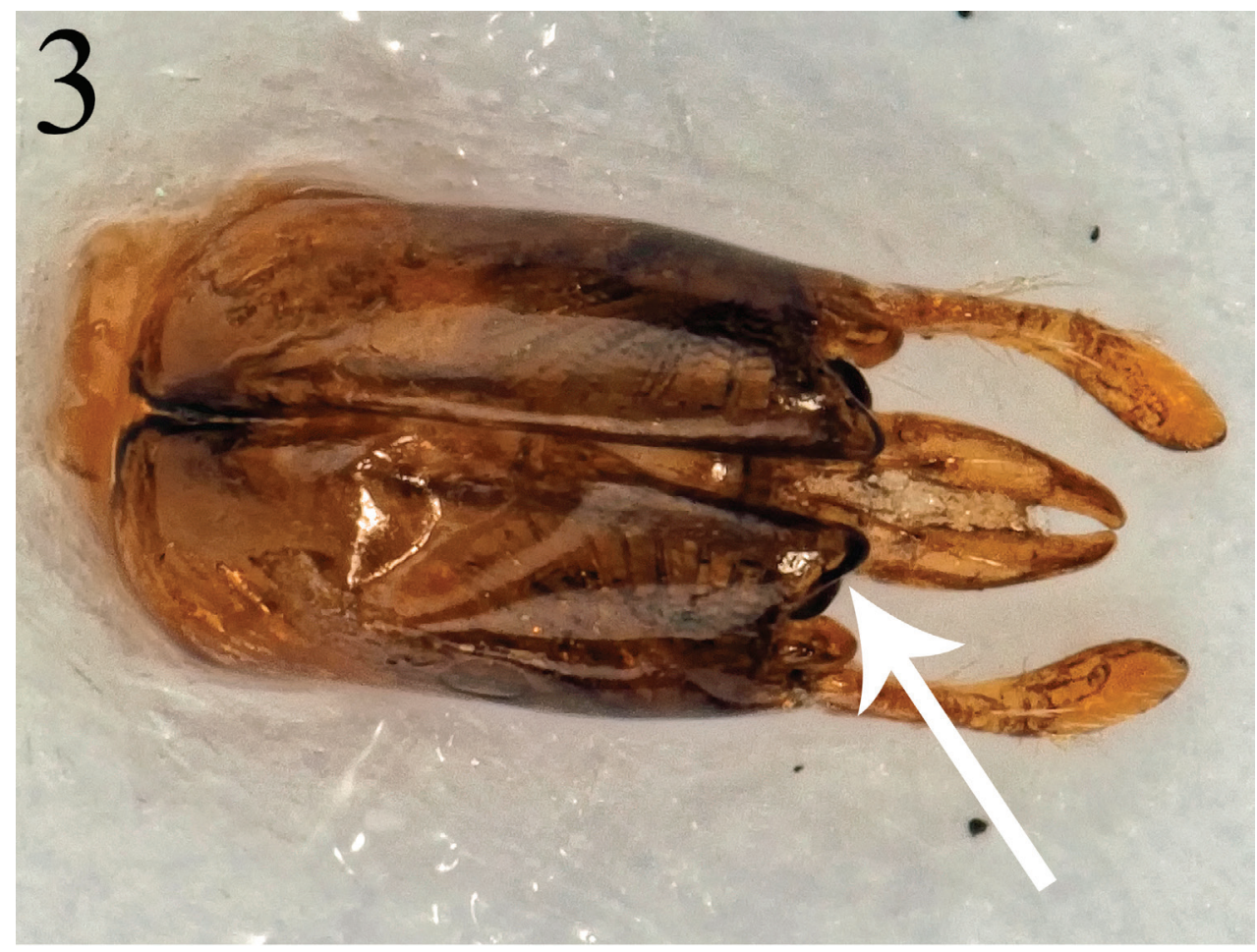

Figure 3. Male genital capsule of Halopanurgus baldocki, with arrow indicating the apical part of the gonocoxa which is produced into a strong triangular point.

are flattened, apically widened, and spatulate (Figs 8-10, 31-32). In the female sex, separation is easy for $H$. baldocki because of its very long glossa (clearly longer than the length of the face, Figs 29-29, the first segment of the labial palpus exceeding the length of segments 2-4 together), but in $H$. fuzetus the length of the glossa cannot be used as the glossa is very short (clearly shorter than the length of the face, Fig. 22), with the first labial palpus not exceeding the length of segments 2-4 together. Instead, the puncturing of the face must be used, with punctures fine and weak in Halopanurgus, subtle, not strongly contrasting with the underlying integument. In Flavipanurgus, the face is strongly and clearly punctate, punctures clearly visible against the integument. This difference is most clearly seen on the frons (compare Figs 22-23).

Halopanurgus can be rapidly separated from Simpanurgus because it lacks distinctively flattened fore tarsi and clavate antennae (Figs 26-27), and from Avpanurgus because of its ' $Y$ ' shaped S7 (Fig. 13) and the genital capsule is very different, lacking the greatly expanded gonocoxae that cover almost the entire dorsal surface (Fig. 5). Note, both Simpanurgus and Avpanurgus are known only from the male sex, so diagnosis in females is not currently possible. As no genetic sequences are available for Simpanurgus or Avpanurgus their broader placement is uncertain. As Simpanurgus may be more closely related to Flavipanurgus than to Halopanurgus, description of the latter at a subgeneric 

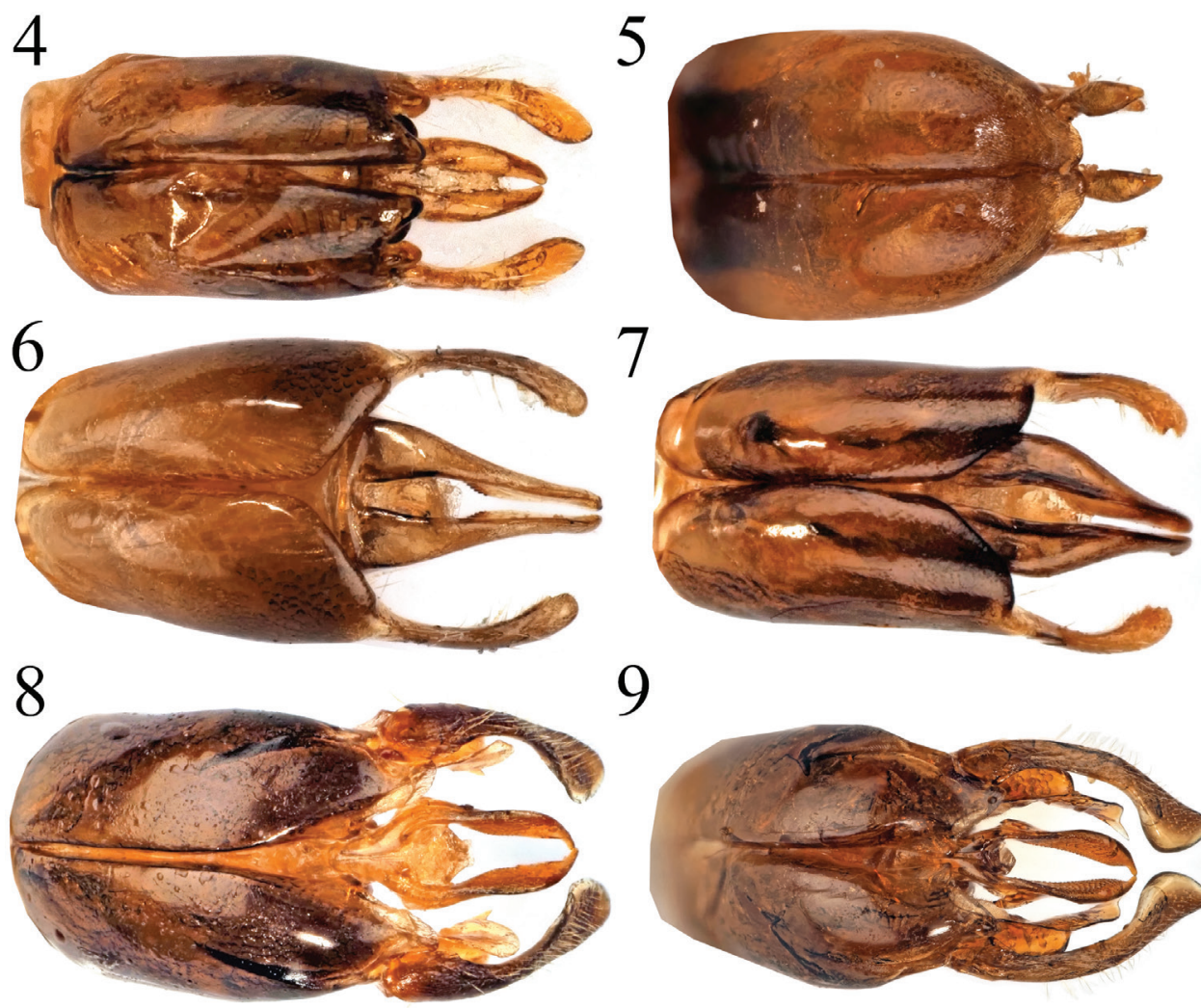

9
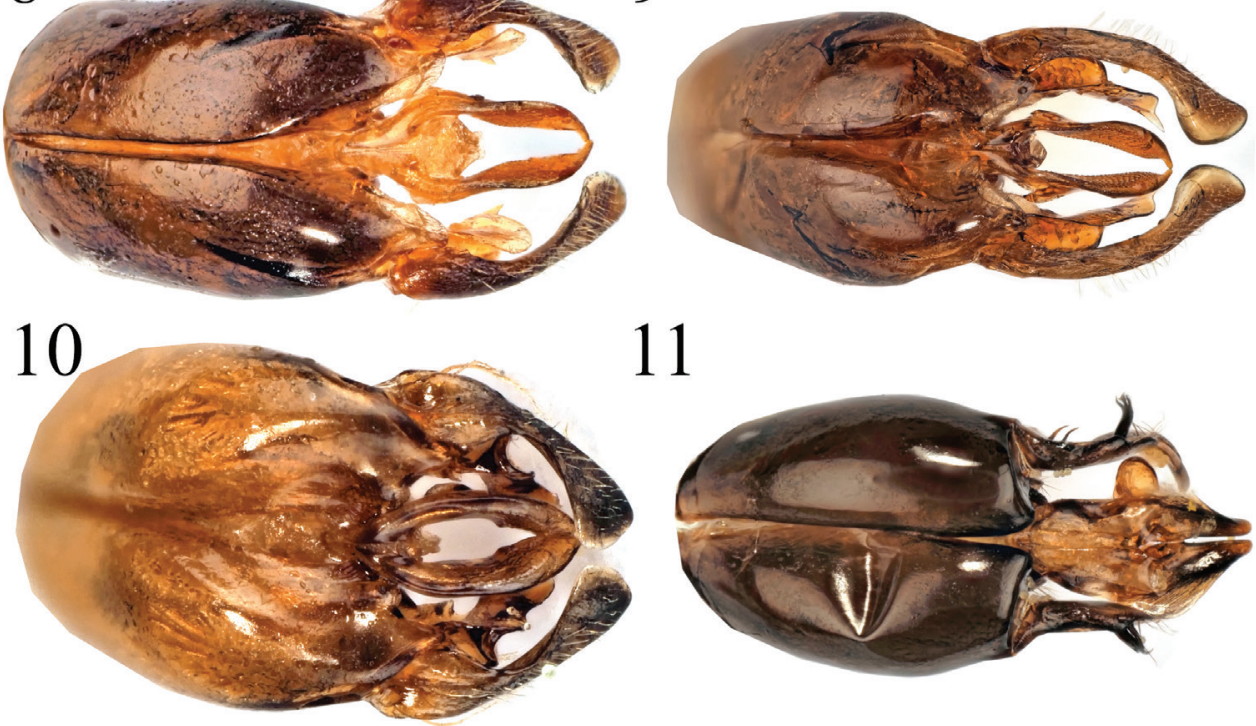

11

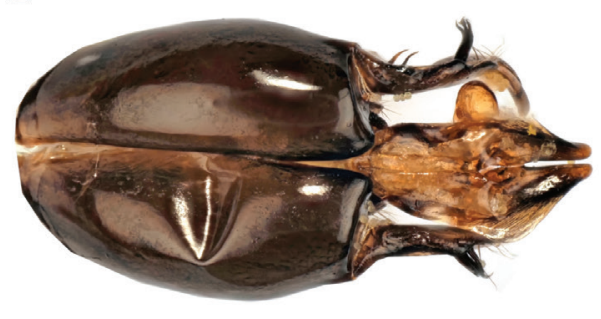

Figures 4-II. Panurgine male genitalia 4 Halopanurgus baldocki 5 Avpanurgus flavofasciatus 6 Camptopoeum (Camptopoeum) frontale $\mathbf{7}$ Camptopoeum (Epimethea) variegatum 8 Flavipanurgus flavus 9 Flavipanurgus venustus 10 Flavipanurgus kastiliensis II Panurgus (Panurgus) calcaratus.

level would necessitate taking a firm position on all these genera. Given this uncertainty, Halopanurgus is described as a genus; future studies may revise the status of these genera when suitable evidence becomes available. Lastly, Halopanurgus can be separated from Panurgus by the presence of yellow markings on the body; these are never present in Panurgus. Moreover, the scopae of Halopanurgus species are composed of simple hairs, lacking the branched hairs which are conspicuously present in Panurgus species. 
Description. Small (4-5 mm) black bees with extensive yellow maculations on head, mesosoma, and metasoma; pronotal lobe, metanotum, and at least some parts of terga always yellow marked, otherwise variable. Male with at least clypeus always yellow, centrally with two small black maculations (Fig. 20). Head broader than long, compound eyes with inner margins parallel. Subantennal sutures essentially straight, outer suture only weakly arched outwards. Facial fovea narrow, slightly narrower than width of lateral ocellus, hairless, equalling length of scape. Ocelloccipital distance short, subequal to width of lateral ocellus.

Face with fine and weak punctures, not strongly contrasting underlying integument (Figs 20, 22). Process of labrum square, as long as wide. Mesoscutum with scattered, fine, and short white hairs; mesepisternum and propodeum with slightly longer white hairs, equally scattered and fine. Forewing with stigma longer than wide, not parallel sided, inner margin weakly curved; two submarginal cells, first submarginal cell longer than second; first recurrent vein entering second submarginal cell; marginal cell apically truncate. Hind tibial spurs unmodified, straight. Basitibial plate present, oval, margins slightly raised; tibial scopa with simple hairs. Tarsal claws with minute inner tooth. Genital capsule simple, gonocoxae apically produced into posteriorly projecting points (Figs 3-4, see also illustrations in Wood and Cross 2017).

Etymology. The name is a combination of the prefix Halo- (Greek for salt) with the genus name Panurgus because of the pronounced affinity for saline soils shown by the two constituent species, both being restricted to saltmarshes, coastal sands, and inland saline lagoons (Wood \& Cross 2017; Cross \& Wood 2018; Fidalgo 2021; TJW unpublished data). The gender is masculine.

Included species. Halopanurgus baldocki (Wood and Cross, 2017) comb. nov. (Figs 28-29, Spain and Portugal, see Fidalgo 2021) and Halopanurgus fuzetus (Patiny, 1999) comb. nov. (Fig. 30, Spain and Portugal).

\section{Flavipanurgus Warncke, 1972}

Flavipanurgus Warncke, 1972: 69. Type species: Panurgus flavus Friese, 1897

Remarks. No genetic samples were available for F granadensis (Warncke, 1987) or F. merceti (Vachal, 1910). However, examination of males of these two species shows that they clearly belong in Flavipanurgus: S7 is deeply excavated apicomedially, and the genital capsule has the gonocoxae lacking apical points along with flattened and apically spatulate gonostyli (Figs 31-32).

Included species. Six species, Flavipanurgus flavus (Friese, 1897), Flavipanurgus granadensis (Warncke, 1987), Flavipanurgus ibericus (Warncke, 1972), Flavipanurgus kastiliensis (Warncke, 1987), Flavipanurgus merceti (Vachal, 1910), and Flavipanurgus venustus (Erichson, 1835). 


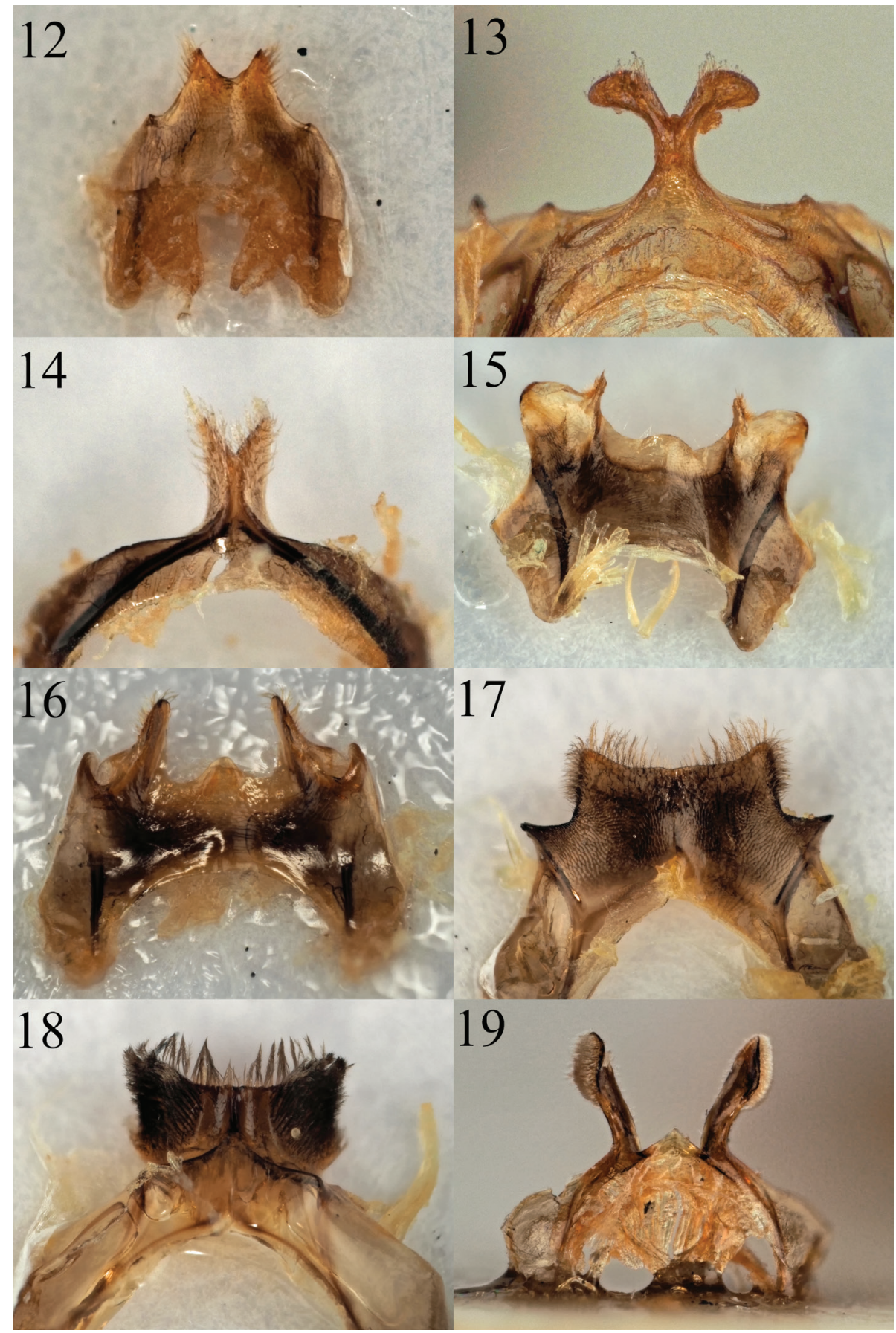

Figures 12-19. Panurgine male sternum seven 12 Halopanurgus baldocki I3 Avpanurgus flavofasciatus 14 Camptopoeum (Epimethea) variegatum $\mathbf{5}$ Flavipanurgus flavus $\mathbf{6} 6$ Flavipanurgus kastiliensis 17 Panurgus (Panurgus) calcaratus 18 Panurgus (Panurgus) dentipes 19 Panurgus (Pachycephalopanurgus) farinosus. 


\section{Panurgus Panzer, 1806}

\section{Panurgus subgenus Panurgus s. str. Panzer, 1806}

Panurgus Panzer, 1806: 209. Type species: Andrena lobata Panzer, $1799=$ Apis calcarata Scopoli, 1763

Eriops Klug, 1807: 207, 227. Type species: Andrena lobata Panzer, $1799=$ Apis calcarata Scopoli, 1763, monobasic.

Eryops Latreille, 1811: 716, unjustified emendation of Eriops Klug, 1807

Panurgus (Euryvalvus) Patiny, 1999c: 316. Type species: Apis banksiana Kirby, 1802, by original designation.

Diagnosis. The subgenus can be separated from Pachycephalopanurgus by the shape of the male $\mathrm{S} 7$ which is always broad, approximately as long as wide, and never strongly apicomedially excavated (Figs 17-18, 45-46). There may be very weak excavations, emarginations, or convexities in the apical margin (e.g. Fig. 45), but the lateral corners are never extended into long, apically produced projections (contrast Figs 19, 47-48). Genital capsule usually with gonostyli robust with strong lateral tuft of clumped hairs that diverges laterally at the midpoint of each gonostylus (Figs 11, 33-36). However, in the former group Euryvalvus the genital capsule is strongly divergent, lacking robust gonostyli with a strong lateral hair tuft (Figs 37-38). These can be recognised by their black, pill-like volsellae which are visible dorsally, their gonostyli which are flattened in the vertical plane, and by their S7, which as in other Panurgus s. str. is broad and lacks long, apically produced and extended projections (Fig. 46). Female Panurgus s. str. specimens cannot be consistently separated from those of Pachycephalopanurgus.

Included species. All Panurgus species previously placed in Panurgus s. str. and Euryvalvus (Patiny 1999c) and subsequent works; the 24 species are detailed in Table 2.

\section{Panurgus subgenus Pachycephalopanurgus Patiny, 1999, stat. rev.}

Panurgus (Pachycephalopanurgus) Patiny, 1999c: 316. Type species: Panurgus rungsii Benoist, 1937, by original designation.

Panurgus (Stenostylus) Patiny, 1999c: 317. [not Stenostylus Pilsbury, 1898]. Type species: Panurgus ovatulus Warncke, 1972, by original designation syn. nov.

Panurgus (Micropanurgus) Patiny, in Ascher and Patiny 2002: 140. Replacement name for Stenostylus Patiny. Type species: Panurgus ovatulus Warncke, 1972, autobasic and by original designation syn. nov.

Diagnosis. The subgenus can be separated from Panurgus s. str. by the shape of the male $S 7$ which has the lateral corners strongly produced into long, apical projections, these bearing a short tuft of hairs laterally (Figs 19, 47-48). S7 therefore appears to be deeply excavated. Genital capsule with gonostyli slender, the majority of species (7 out 


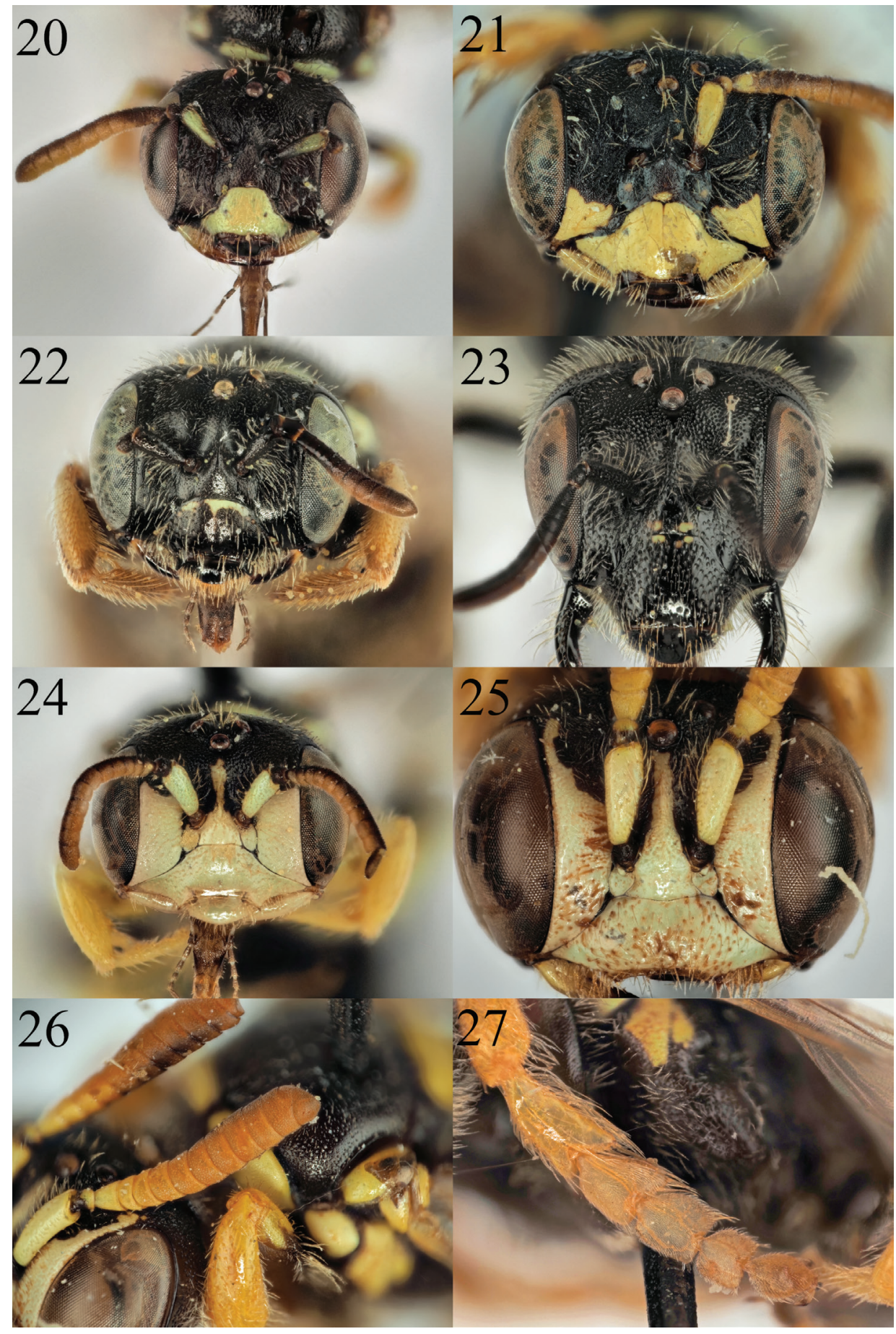

Figures 20-27. Panurgine faces $\mathbf{2 0}$ Halopanurgus baldocki comb. nov. male $\mathbf{2 I}$ Avpanurgus flavofasciatus male $\mathbf{2 2}$ Halopanurgus fuzetus comb. nov. female $\mathbf{2 3}$ Flavipanurgus granadensis female $\mathbf{2 4}$ Flavipanurgus kastiliensis male $\mathbf{2 5}$ Simpanurgus phyllopodus male, including $\mathbf{2 6}$ male antennae and $\mathbf{2 7}$ male fore tarsi. 
Table 2. Revised subgeneric classification system for the genus Panurgus, with all globally known species.

\begin{tabular}{ll}
\hline \multicolumn{1}{c}{ Subgenus Panurgus s. str. Panzer, 1806 } & Subgenus Pachycephalopanurgus Patiny, 1999 stat. rev. \\
\hline Panurgus afghanensis Warncke, 1972 & Panurgus acutus Patiny, 2002 \\
Panurgus avarus Warncke, 1972 & Panurgus calceatus Pérez, 1895 \\
Panurgus banksianus (Kirby, 1802) & Panurgus canescens Latreille, 1811 \\
Panurgus buteus Warncke, 1972 & Panurgus convergens Pérez, 1895 \\
Panurgus calcaratus (Scopoli, 1763) & Panurgus farinosus Warncke, 1972 \\
Panurgus canarius Warncke, 1972 & Panurgus meridionalis Patiny, Ortiz \& Michez, 2005 \\
Panurgus cephalotes Latreille, 1811 & Panurgus minor Warncke, 1972 \\
Panurgus corsicus Warncke, 1972 & Panurgus nigriscopus Pérez, 1895 \\
Panurgus cyrenaikensis Warncke, 1972 & Panurgus ovatulus Warncke, 1972 \\
Panurgus dargius Warncke, 1972 & Panurgus rungsii Benoist, 1937 \\
Panurgus dentatus Friese, 1901 & \\
Panurgus dentipes Latreille, 1811 & \\
Panurgus intermedius Rozen, 1971 & \\
Panurgus maroccanus Pérez, 1895 & \\
Panurgus niloticus Warncke, 1972 & \\
Panurgus oblitus Warncke, 1972 & \\
Panurgus perezi Saunders, 1882 & \\
Panurgus pici Pérez, 1895 & \\
Panurgus platymerus Pérez, 1895 & \\
Panurgus posticus Warncke, 1972 & \\
Panurgus pyropygus Friese, 1901 & \\
Panurgus siculus Morawitz, 1872 & \\
Panurgus sidensis Warncke, 1987 & \\
Panurgus vachali Pérez, 1895 &
\end{tabular}

of 10) with a clear lamelliform projection that diverges at the midpoint of each gonostylus (Figs 39-42, 44). However, in the former group Micropanurgus (three species), this lamelliform projection is greatly reduced and inconspicuous (Fig. 43). Gonocoxae always with strongly projecting points. Female Pachycephalopanurgus specimens cannot be consistently separated from Panurgus s. str.

Included species. All Panurgus species previously placed in Pachycephalopanurgus and Micropanurgus (Patiny 1999c; Ascher and Patiny 2002; Patiny 2002); the 10 species are detailed in Table 2.

\section{Genera closely related to Panurgus}

Compared to the baseline of Michener (2007), these changes result in the elevation of Flavipanurgus and Simpanurgus from subgenera of Panurgus, and the re-establishment of two subgenera within Panurgus, Panurgus s. str. and Pachycephalopanurgus. The description of the genus Halopanurgus and the reorganisation of genera within panurgine tribes means that it is necessary to write a new key to facilitate their identification. Within the scope of this paper, we provide a key to the genera closely related to Panurgus, specifically the five genera, Avpanurgus, Flavipanurgus, Halopanurgus, Simpanurgus, and Panurgus. As Avpanurgus flavofasciatus (Warncke, 1972) 


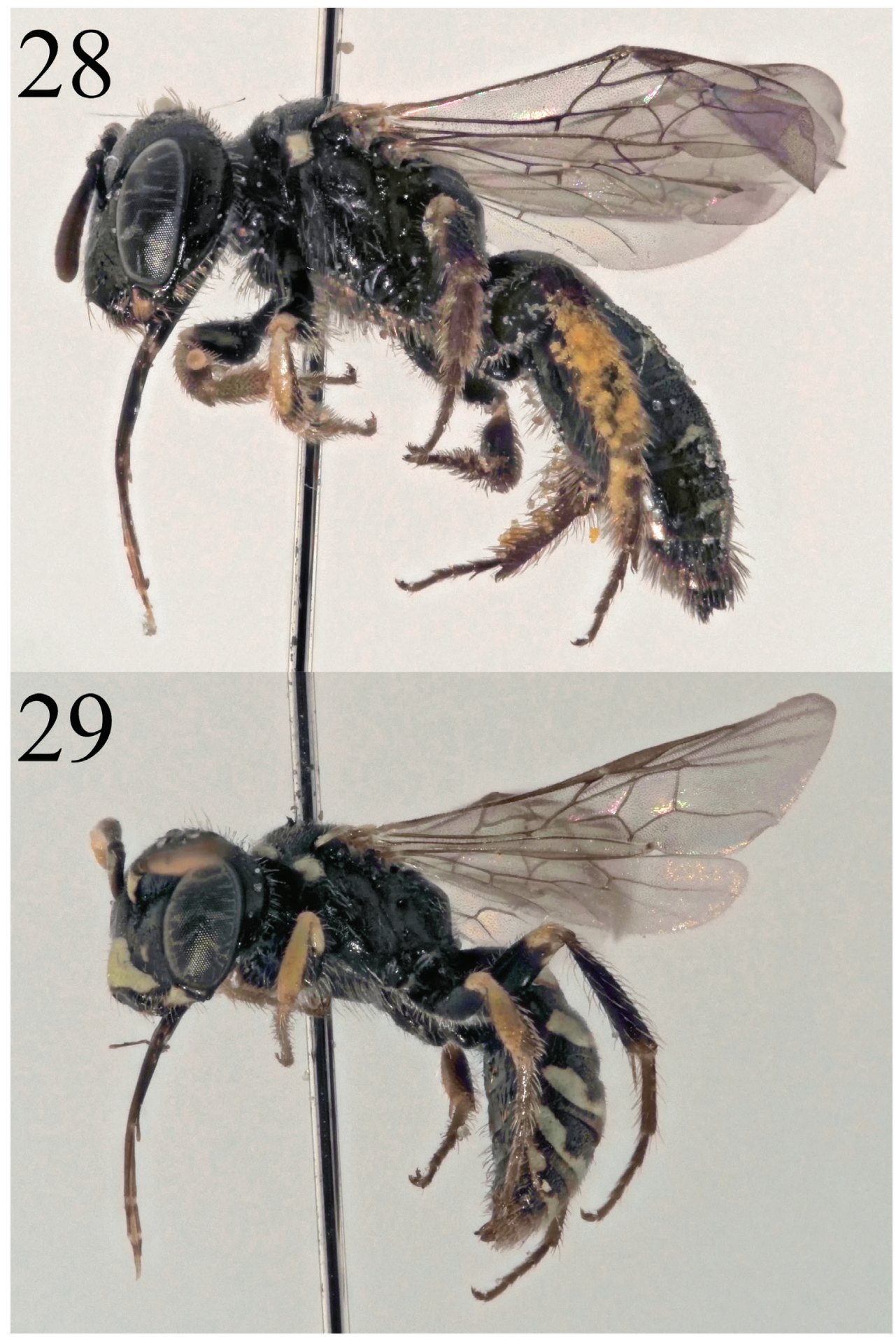

Figures 28-29. Halopanurgus baldocki comb. nov. profile 28 female 29 male. 


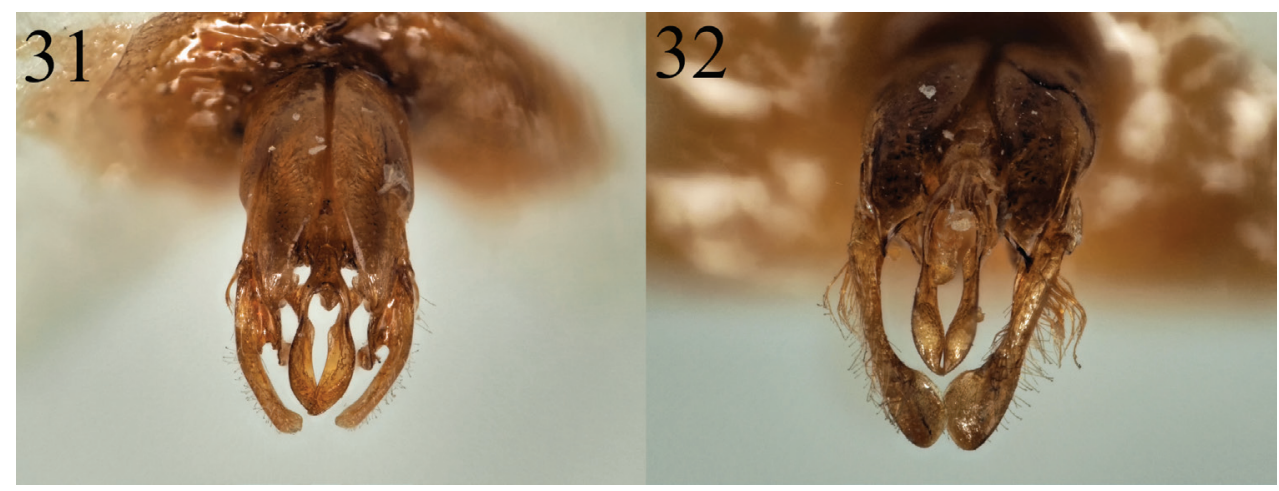

Figures 3 I-32. Flavipanurgus male genitalia 3 I Flavipanurgus granadensis 32 Flavipanurgus merceti.

and Simpanurgus phyllopodus (Warncke, 1972) are known only from the type series (comprised entirely of males), no samples were available for genetic analysis and they are therefore absent from the tree of Bossert et al. (2022). However, we retain these species in this group of related genera because of male genital morphology and for biogeographic reasons, as all genera are restricted, to or show a centre of diversity (greatest number of genera and extant taxa), in the West Mediterranean region. Specifically, the genital capsule of Simpanurgus resembles that of Flavipanurgus in its gonocoxae which lack apical points, their inner margin rounded; in its large penis valves, the blades of which are flattened in the vertical plane; and there are also similarities in the structure of S7 which is broader than long and deeply excavated medially with a tiny apicomedial tooth (see Warncke 1972, compare Figs 8-10, 15-16, 31-32, S7 of S. phyllopodus very similar to F. kastiliensis). In Avpanurgus, the gonostyli and penis valves are thin and delicate and have similarities with those of Halopanurgus, but the gonocoxae are grossly enlarged (Fig. 5). The shape of S7 is also similar, generally as long as broad, and with an apicomedial notch, though this is much more strongly pronounced, with a narrow basal stem (Fig. 13). The face is similar, being less extensively punctured (Figs 20-23) and with less yellow maculation than in Flavipanurgus and Simpanurgus (Figs 20-21, 24-25).

\section{Key to the genera closely related to Panurgus}

$1 \quad$ Male S7 with extremely narrow stem, medially with apical projection that is deeply notched, forming a ' $\mathrm{Y}$ ' shape, apical breadth greater than length (Fig. 13). Gonocoxae grossly enlarged, covering entire dorsal surface of capsule, only apexes of gonostyli and penis valves extend beyond its apical extent (Fig. 5)

Avpanurgus Warncke

- Male S7 narrow or broad, notched or not, but never with a 'Y' shaped apical projection (Figs 12, 15-19, 45-48). Gonocoxae not grossly enlarged, base of both gonostyli and penis valves visible in dorsal view . 
2 Male antennae clavate, clearly broadened apically (Fig. 26). Fore tarsi with all segments strongly expanded and flattened (Fig. 27). Male S7 medially excavated Simpanurgus Warncke

- Male antennae not clavate, apical segments not noticeably broader than basal segments (e.g. Figs 20, 24). Fore tarsi normal, not noticeably expanded or flattened. Male S7 medially excavated or not 3

3 Male S7 comparatively narrow, slightly broader than long, medially notched (Fig. 12). Genitalia with gonocoxae apically produced into strong points (Figs 3-4). Body black with yellow markings. Face with reduced punctation, punctures fine, superficial, not strongly standing out from underlying integument (Figs 20, 22). Tongue over twice the length of face or not (Figs 28-30)

Halopanurgus gen. nov.

- $\quad$ Male S7 broad, much broader than long, strongly excavated medially or not, but not narrowly notched (Figs 15-19). Genitalia with gonocoxae either without apical points (Figs 8-10,31-32,37-38), or if with apical points (Figs 11, 33-36, 39-44), then body black, never with yellow markings. Face with clear punctation (Fig. 23). Tongue never over twice as long as face.......4 4 Body with yellow markings (except female of $F$. flavus (Friese, 1897)). Scopal hairs simple, not spiralled. Genitalia with gonocoxae lacking apical points, inner margin rounded, gonostyli flattened in lateral plane, spatulate (Figs 8-10, 31-32) Flavipanurgus Warncke

- $\quad$ Body never with yellow markings. Scopal hairs distinctively and minutely spiralled. Genitalia with gonocoxae usually with apical points (Figs 11, 33-36, 39-44), if absent then gonostyli flattened in vertical plane, never in lateral plane and never spatulate (Figs 37-38)

Panurgus Panzer

\section{Pollen preferences}

A total of 93 pollen loads were analysed from nine Panurgus species (Table 3). All pollen was collected from Asteraceae, which is why we assume all species to be oligolectic or suspect them to be oligolectic where sample sizes were too low to be confident. Panurgus (Panurgus) showed a strong association with the subfamily Cichorioideae, whereas $P$. (Pachycephalopanurgus) showed a strong association with the subfamily Asteroideae, though confidence in the strength of this relationship is limited by the very low sample sizes available for North African species.

\section{Discussion}

As demonstrated at a global scale (Pisanty et al. 2021; Bossert et al. 2022), the use of ultraconserved elements for phylogenetic analysis has considerably improved our understanding on the evolutionary relationships of andrenid bees, including the subfamily 

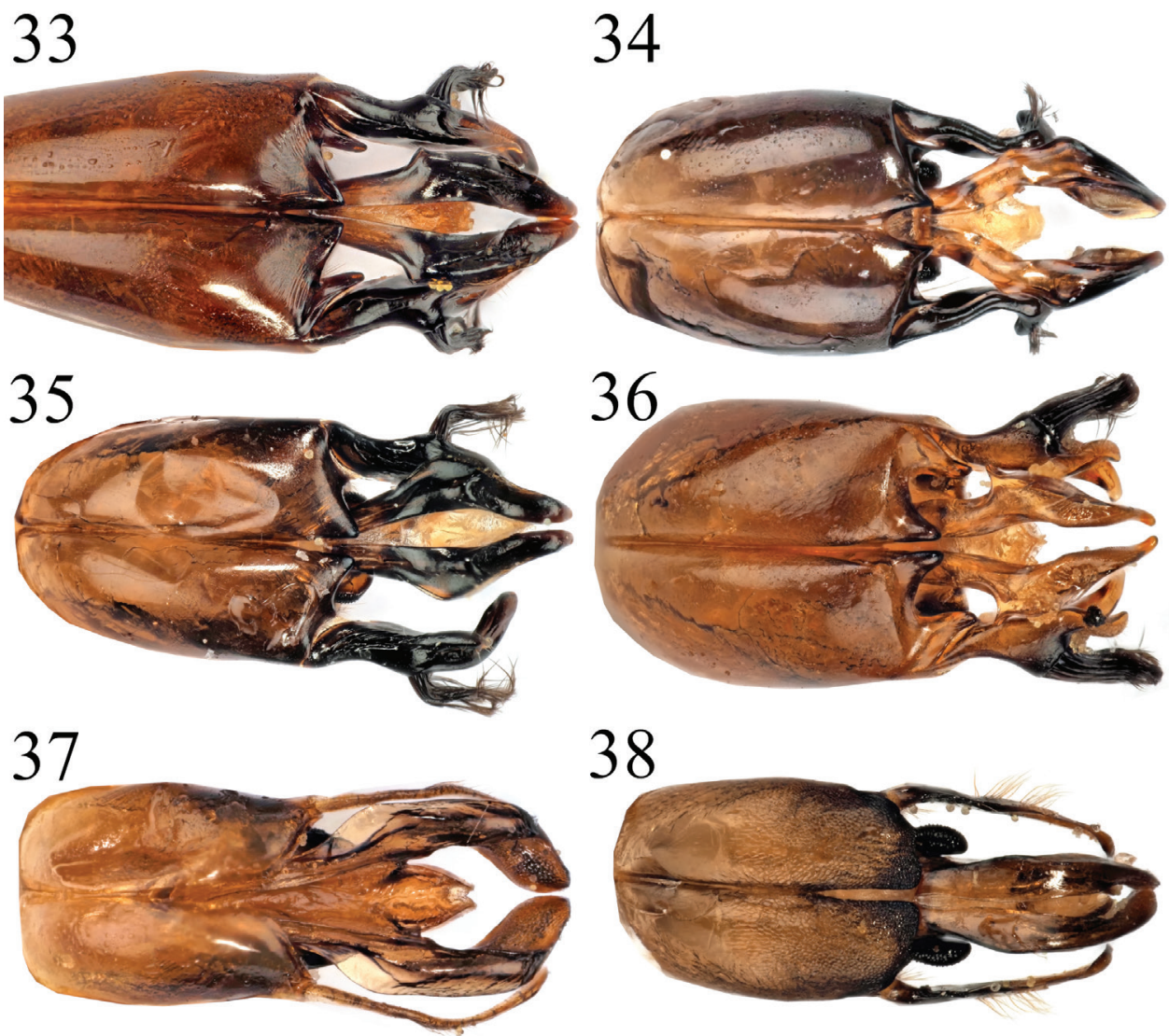

Figures 33-38. Panurgus (Panurgus s. str.) male genitalia 33 Panurgus cephalotes 34 Panurgus dentipes 35 Panurgus maroccanus 36 Panurgus perezi 37 Panurgus banksianus 38 Panurgus pyropygus.

Panurginae. In the case of the Panurginae, the reciprocal analysis of morphological characters given our robust molecular phylogeny revealed that certain morphological features used to characterise genera of Old World Panurginae have been overvalued in the past and have incorrectly resulted in the association of Halopanurgus baldocki with the genus Camptopoeum.

Albeit separated by -50 million years of divergence time (Bossert et al. 2022), certain species of Panurgini and Melitturgini share remarkably similar morphological features, leading authors to conclude close phylogenetic relationships until very recently. The most pertinent example is Camptopoeum, which was included with the two-celled members of the Panurgini by Michener (2007). Halopanurgus baldocki was described as a Camptopoeum (Camptopoeum) because of the elongate tongue, in which the first segment of the labial palpus is about as long as the second to fourth segments taken together. Indeed, based only on tongue morphology, H. baldocki is more similar to Camptopoeum (Camptopoeum) than it is to its sister species Halopanurgus fuzetus, 


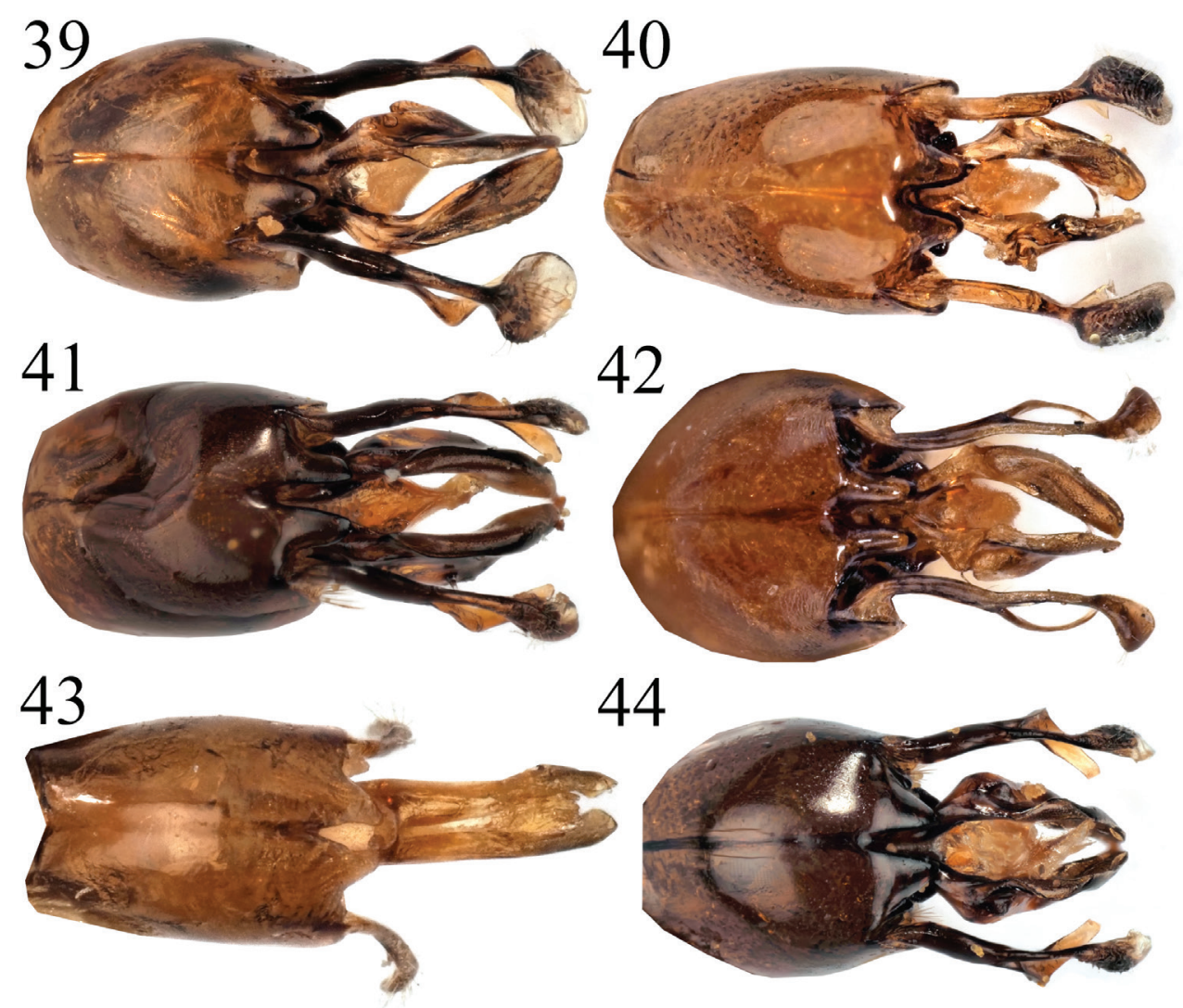

Figures 39-44. Panurgus (Pachycephalopanurgus) male genitalia 39 Panurgus calceatus 40 Panurgus canescens 41 Panurgus convergens 42 Panurgus farinosus 43 Panurgus minor 44 Panurgus rungsii.

and more similar to Camptopoeum (Camptopoeum) than to Camptopoeum (Epimethea), which have very short glossa. Tongue length within Old World panurgines is therefore clearly homoplasious.

This confusion that arose from misleading tongue morphology serves as a cautionary tale into panurgine classification. Tongue length can clearly be a labile morphological character and is not necessarily suitable for diagnosing suprageneric taxa (Danforth et al. 2019). Bee mouthparts represent a particularly intuitive example of a morphological structure facing selective pressure. All bee species examined in this study exhibit some degree of host plant specialization and most seem to be true oligoleges. It is expected that tongue length varies among species in respect to their host plant, and the appearance of bee species with physically long tongues within the short-tongued bee families such as Andrenidae (e.g. Shimizu et al. 2014), Colletidae (e.g. Laroca et al. 1989; Rozen and Wyman 2015), and Halictidae (e.g. Burger 2020) is well established, usually being associated with particular floral shapes that necessitate morphological adaptation to access particular resources. In the case of $H$. baldocki, their long tongues are used to access the 


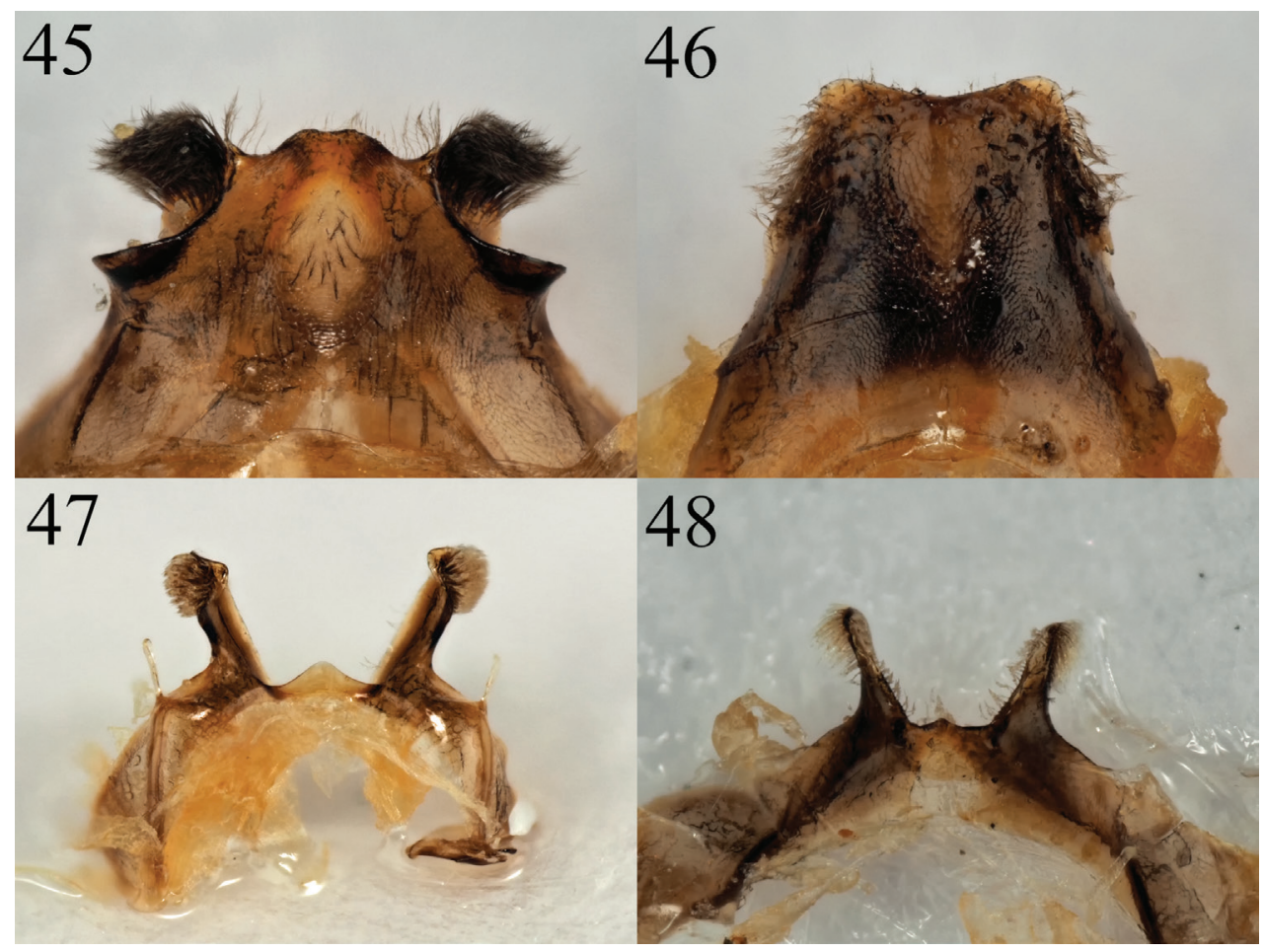

Figures 45-48. Sternum 7 for members of the former four subgenera of Panurgus 45 Panurgus (Panurgus) cephalotes 46 Panurgus (Euryvalvus) banksianus 47 Panurgus (Pachycephalopanurgus) canescens 48 Panurgus (Micropanurgus) ovatulus.

nectaries of its host Frankenia laevis (Frankeniaceae) which are found at the base of a tubular corolla, necessitating a long tongue for a bee of only $4 \mathrm{~mm}$ in length (Wood and Cross 2017). Halopanurgus fuzetus in turn visits species of Spergularia (Caryophyllaceae, Wood and Cross 2017), which have an open floral structure, and therefore do not require a long tongue to access the nectaries despite their equally small body size. The -7.5 million years of divergence time between the two Halopanurgus species (Bossert et al. 2022) was sufficient to allow their tongue morphologies to diverge, and it is intuitive that they represent adaptations towards nectar uptake from different host plants. This mirrors the situation in Camptopoeum (Camptopoeum) and Camptopoeum (Epimethea), which based on the very limited number of species whose foraging niches are well understood are specialists of Centaurea (Asteraceae) and Apiaceae, respectively (Friese 1926, TJW unpublished data). Like Frankenia, Centaurea flowers have individual florets in which nectar is found at the bottom of a tubular corolla, whereas in the Apiaceae used by Camptopoeum (Epimethea) species, the floral structure is open and does not require a long tongue to access nectaries.

Against this context, the description of new panurgine genera from the Arabian Peninsula and Central Asia (Engel et al. 2019) based primarily on tongue morphology raises interesting questions. Placing close to Flavomeliturgula Patiny (now within a broad Panurgini, Bossert et al. 2022; Meliturgulina sensu Engel et al. 2019), the genus 
Belliturgula Engel (Saudi Arabia) is diagnosed predominantly on the basis of tongue characters combined with body colouration (Engel et al. 2019), and the genus Khuzimelissa Engel (Iran and Pakistan) is diagnosed mainly on the basis of tongue characters and additionally on the shape of the outer antennal sulcus. Both genera are monotypic, and were described from female material only, with no male specimens known. Given the labile nature of tongue length within Panurginae, and the lack of male material that was crucial for morphologically confirming differences between the genera in the present study, it is difficult to assess the status of these genera and the relationships between the species related to Flavomeliturgula with confidence.

From a biogeographical perspective, the genera closely related to Panurgus that have been confidently placed through genetic analysis (Bossert et al. 2022) show a West Mediterranean distribution, restricted to Iberia (Halopanurgus and Flavipanurgus) or with particular diversity in the western Maghreb (Panurgus; Patiny and Gaspar 2000; Patiny 2001; Lhomme et al. 2020). The only known collecting localities for Avpanurgus and Simpanurgus being in Algeria and Spain, respectively (Warncke 1972; Patiny 2001), means that they align with this overall pattern; the centres of diversity for other Panurgini clades are located further east, such as Asia (taxa related to Panurginus), and the Middle East to sub-Saharan Africa (taxa related to Meliturgula and Mermiglossa), and also for Camptopoeum whose centre of diversity is the Middle East (Patiny 2001). Though the placement of Avpanurgus and Simpanurgus in the group of genera related to Panurgus requires additional molecular investigation and confirmation, it forms the basis of a suitable hypothesis should fresh specimens become available.

A further line of evidence that can help inform our understanding of panurgine groups are their pollen preferences. Though the division of Panurgus into two subgenera is justified on the basis of the strong molecular and morphological evidence in the male sex, this division between Panurgus s. str. and Pachycephalopanurgus may also be reflected in their use of Asteraceae pollen. All known Panurgus species are oligoleges of Asteraceae, but Panurgus s. str. are specialists of the subfamily Cichorioideae (Table 3, see Münster-Swendsen 1970; Westrich 1989 for P. calcaratus, P. banksianus, and P. dentipes; Rozen 1971 for P. maroccanus, P. intermedius, P. pici), whereas Pachycephalopanurgus appear to be specialists of the subfamily Asteroideae (Table 3, see Cross 2020 for $P$. meridionalis). Clearly, a much greater sampling effort is needed for North African Pachycephalopanurgus species, but a nominal specialisation on Asteroideae forms the basis of a testable hypothesis. Why these two lineages of Panurgus seem to divide their efforts between these two lineages of Asteraceae is unclear, but a proposed mechanism is related to their pollen-collecting behaviour. Specifically, when foraging on Astericus (Asteroideae), Pachycephalopanurgus species focus on the non-ligulate disc florets and sweep pollen into their scopae whilst rapidly pulsing and moving their metasoma, a technique that seems unlikely to be effective in the Cichorioideae where only ligulate florets are present (Cross 2020). More broadly, with their spiralled scopal hairs and specialisation on Asteraceae, Panurgus appear to represent another independent lineage of bees that have converged on carrying their pollen dry (Portman and Tepedino 2017), in contrast to their closest relatives Flavipanurgus and Halopanurgus which carry their pollen moistened by nectar (Wood and Cross 2017; Cross and Wood 2018). 
Table 3. Host plant spectrum and inferred category of host use in Panurgus species. $n$ total number of pollen loads, $N$ number of pollen loads from different localities. Plant taxa AST, Asteraceae.

\begin{tabular}{|c|c|c|c|c|c|c|}
\hline Species & $n$ & $N$ & $\begin{array}{l}\text { Results of microscopic } \\
\text { analysis of pollen grains ( } \% \\
\text { pollen grains) }\end{array}$ & $\begin{array}{c}\text { \% Pure loads } \\
\text { of preferred } \\
\text { host }\end{array}$ & $\begin{array}{l}\% \text { Loads } \\
\text { with pre- } \\
\text { ferred host }\end{array}$ & Host range \\
\hline \multicolumn{7}{|l|}{ P. (Panurgus) } \\
\hline Panurgus cephalotes & 28 & 15 & $\begin{array}{c}\text { AST (Cichorioideae) 98.9, } \\
\text { AST (Asteroideae) } 1.1\end{array}$ & 100.0 & 100.0 & $\begin{array}{c}\text { Broadly oligolectic (Astera- } \\
\text { ceae, Cichorioideae) }\end{array}$ \\
\hline $\begin{array}{l}\text { Panurgus maroc- } \\
\text { canus }\end{array}$ & 14 & 5 & $\begin{array}{c}\text { AST (Cichorioideae) 91.1, } \\
\text { AST (Asteroideae) } 9.9\end{array}$ & 100.0 & 100.0 & $\begin{array}{l}\text { Possibly broadly oligolectic } \\
\text { (Asteraceae, Cichorioideae) }\end{array}$ \\
\hline Panurgus perezi & 23 & 14 & AST (Cichorioideae) 100.0 & 100.0 & 100.0 & $\begin{array}{c}\text { Broadly oligolectic (Astera- } \\
\text { ceae, Cichorioideae) }\end{array}$ \\
\hline \multicolumn{7}{|l|}{$\begin{array}{l}\text { P. (Pachycephalo- } \\
\text { panurgus) }\end{array}$} \\
\hline Panurgus calceatus & 10 & 2 & $\begin{array}{l}\text { AST (Asteroideae) 65.9, } \\
\text { AST (Cichorioideae) 26.0, } \\
\text { AST (Carduoideae) } 8.1\end{array}$ & 100.0 & 100.0 & $\begin{array}{l}\text { Broadly oligolectic (As- } \\
\text { teraceae) }\end{array}$ \\
\hline Panurgus canescens & 12 & 8 & AST (Asteroideae) 100.0 & 100.0 & 100.0 & $\begin{array}{c}\text { Broadly oligolectic (Astera- } \\
\text { ceae, Asteroideae) }\end{array}$ \\
\hline Panurgus convergens & 2 & 2 & AST (Asteroideae) 100.0 & 100.0 & 100.0 & $\begin{array}{c}\text { Possibly broadly oligolectic } \\
\text { (Asteraceae, Asteroideae) }\end{array}$ \\
\hline Panurgus nigriscopus & 1 & 1 & AST (Asteroideae) 100.0 & 100.0 & 100.0 & $\begin{array}{c}\text { Possibly broadly oligolectic } \\
\text { (Asteraceae, Asteroideae) }\end{array}$ \\
\hline Panurgus ovatulus & 1 & 1 & AST (Asteroideae) 100.0 & 100.0 & 100.0 & $\begin{array}{c}\text { Possibly broadly oligolectic } \\
\text { (Asteraceae, Asteroideae) }\end{array}$ \\
\hline Panurgus rungsii & 2 & 2 & $\begin{array}{l}\text { AST (Asteroideae) 94.0, } \\
\text { AST (Carduoideae) } 6.0\end{array}$ & 100.0 & 100.0 & $\begin{array}{c}\text { Possibly broadly oligolectic } \\
\text { (Asteraceae, Asteroideae) }\end{array}$ \\
\hline
\end{tabular}

\section{Acknowledgements}

Our thanks go to Esther Ockermüller and Martin Schwarz for access to the Warncke Collection, loan of material, and hospitality at Linz, and to Ian Cross for access to his personal collection. We also thank Pierre Rasmont for substantial assistance with photography. TJW is supported by an F.R.S.-FNRS fellowship "Chargé de recherches". This work was supported by NSF grant DEB-2127744 and a Peter Buck fellowship to SB. The authors thank Laurence Packer, Zachary Portman, and an anonymous reviewer for comments that substantially improved the manuscript.

\section{References}

Ascher JS, Patiny S (2002) A new name for the bee subgenus Stenostylus (Hymenoptera: Andrenidae). Entomological News 113: 140-140.

Ascher J, Engel MS (2017) A new species of Mermiglossa from Kenya, with comments on the arrangement of Old World Panurginae (Hymenoptera: Andrenidae). Journal of Melittology 75: 1-11. http://dx.doi.org/10.17161/jom.v0i75.6717 
Ascher JS (2004) Systematics of the bee family Andrenidae (Hymenoptera: Apoidea). PhD thesis. Cornell University, USA.

Bankevich A, Nurk S, Antipov D, Gurevich AA, Dvorkin M, Kulikov AS, Lesin VM, Nikolenko SI, Pham S, Prjibelski AD (2012) SPAdes: a new genome assembly algorithm and its applications to single-cell sequencing. Journal of Computational Biology 19: 455-477. https://doi.org/10.1089/cmb.2012.0021

Borowiec ML (2019) Spruceup: fast and flexible identification, visualization, and removal of outliers from large multiple sequence alignments. Journal of Open Source Software 4: e1635. https://doi.org/10.21105/joss.01635

Bossert S, Copeland RS, Sless TJL, Branstetter MG, Gillung JP, Brady SG, Danforth BN, Policarová J, Straka J (2020) Phylogenomic and morphological reevaluation of the bee tribes Biastini, Neolarrini, and Townsendiellini (Hymenoptera: Apidae) with description of three new species of Schwarzia. Insect Systematics and Diversity 4: 1-29. https://doi. org/10.1093/isd/ixaa013

Bossert S, Wood TJ, Patiny S, Michez D, Almeida EAB, Minckley RL, Packer L, Neff JL, Copeland RS, Straka J, Pauly A, Griswold T, Brady SG, Danforth BN, Murray EA (2022) Phylogeny, biogeography and diversification of the mining bee family Andrenidae. Systematic Entomology, in press. https://doi.org/10.1111/syen.12530

Branstetter MG, Longino JT, Ward PS, Faircloth BC (2017) Enriching the ant tree of life: enhanced UCE bait set for genome-scale phylogenetics of ants and other Hymenoptera. Methods in Ecology and Evolution 8: 768-776. https://doi.org/10.1111/2041-210X.12742

Burger R (2020) Beobachtungen zum Blütenbesuch und Pollensammeln von Lasioglossum buccale (Pérez 1903) (Hymenoptera: Anthophila). Ampulex 11: 34-40.

Castresana J (2000) Selection of conserved blocks from multiple alignments for their use in phylogenetic analysis. Molecular Biology and Evolution 17: 540-552. https://doi. org/10.1093/oxfordjournals.molbev.a026334

Cross I (2020) The pollen host of Panurgus meridionalis (Hymenoptera: Andrenidae). Entomologist's Monthly Magazine 156: 1-6. https://doi.org/10.31184/M00138908.1561.4018

Cross I, Wood TJ (2018) New data on the Iberian endemic bee genus Flavipanurgus Warncke (Hymenoptera: Apoidea: Andrenidae): Ecological and genomic data reveal a hidden species. Zootaxa 4521: 563-572. https://doi.org/10.11646/zootaxa.4521.4.5

Danforth BN, Sauquet H, Packer L (1999) Phylogeny of the bee genus Halictus (Hymenoptera: Halictidae) based on parsimony and likelihood analyses of nuclear EF-1a Sequence Data. Molecular Phylogenetics and Evolution 13: 605-618. https://doi.org/10.1006/mpev.1999.0670

Danforth BN, Minckley RL, Neff JL (2019) The solitary bees: biology, evolution, conservation. Princeton University Press, Princeton, 488 pp. https://doi.org/10.2307/j.ctvd1c929

Dorchin A, López-Uribe MM, Praz CJ, Griswold T, Danforth BN (2018) Phylogeny, new generic-level classification, and historical biogeography of the Eucera complex (Hymenoptera: Apidae). Molecular Phylogenetics and Evolution 119: 81-92. https://doi.org/10.1016/j. ympev.2017.10.007

Engel MS (2005) Family-group names for bees (Antophila). American Museum Novitates, 3476: 1-33. https://doi.org/10.1206/0003-0082(2005)476[0001:FNFBHA]2.0.CO;2 
Engel MS (2006) A new genus of minute ammobatine bees (Hymenoptera: Apidae). Acta Entomologica Slovenica 14: 113-121.

Engel MS (2019) New genera of meliturguline bees from Saudi Arabia and Persia, with notes on related genera and a key to the Arabian fauna (Hymenoptera: Andrenidae). Journal of Hymenoptera Research 69: 1-21. https://doi.org/10.3897/jhr.69.32561

Faircloth BC (2016) PHYLUCE is a software package for the analysis of conserved genomic loci. Bioinformatics 32: 786-788. https://doi.org/10.1093/bioinformatics/btv646

Fidalgo PA (2021) First record of Camptopoeum (Camptopoeum) baldocki Wood \& Cross, 2017 from Spain (Hymenoptera, Apoidea, Andrenidae). Boletín de la Sociedad Entomológica Aragonesa (S.E.A.) 68: 433-434.

Friese H (1926) Die Bienen, Wespen, Grab-und Goldwespen Insekten Mitteleuropas. Franckh'sche Verlagshandlung, Stuttgart, 192 pp.

Hoang DT, Chernomor O, von Haeseler A, Minh BQ, Vinh LS (2018) UFBoot2: improving the ultrafast bootstrap approximation. Molecular Biology and Evolution 35: 518-522. https://doi.org/10.1093/molbev/msx281

Kalyaanamoorthy S, Minh BQ, Wong TKF, von Haeseler A, Jermiin LS (2017) ModelFinder: fast model selection for accurate phylogenetic estimates. Nature Methods 14: e587. https:// doi.org/10.1038/nmeth.4285

Katoh K, Standley DM (2013) MAFFT multiple sequence alignment software version 7: improvements in performance and usability. Molecular Biology and Evolution 30: 772-780. https://doi.org/10.1093/molbev/mst010

Lanfear R, Calcott B, Ho SYW, Guindon S (2012) PartitionFinder: Combined selection of partitioning schemes and substitution models for phylogenetic analyses. Molecular Biology and Evolution 29: 1695-1701. https://doi.org/10.1093/molbev/mss020

Lanfear R, Calcott B, Kainer D, Mayer C, Stamatakis A (2014) Selecting optimal partitioning schemes for phylogenomic datasets. BMC Evolutionary Biology 14: e82. https:/doi. org/10.1186/1471-2148-14-82

Laroca S, Michener CD, Hofmeister RM (1989) Long mouthparts among "short-tongued" bees and the fine structure of the labium in Niltonia (Hymenoptera: Colletidae). Journal of the Kansas Entomological Society 62: 400-410.

Lhomme P, Michez D, Christmann S, Scheuchl E, Abdouni IE, Hamroud L, Ihsane O, Sentil A, Smaili MC, Schwarz M, Dathe HH, Straka J, Pauly A, Schmid-Egger C, Patiny S, Terzo M, Müller A, Praz C, Risch S, Kasparek M, Kuhlmann M, Wood TJ, Bogusch P, Ascher JS, Rasmont P (2020) The wild bees (Hymenoptera: Apoidea) of Morocco. Zootaxa 4892: 1-159. https://doi.org/10.11646/zootaxa.4892.1.1

Litman JR, Griswold T, Danforth BN (2016) Phylogenetic systematics and a revised generic classification of anthidiine bees (Hymenoptera: Megachilidae). Molecular Phylogenetics and Evolution 100: 183-196. https://doi.org/10.1016/j.ympev.2016.03.018

Michener CD (2007) The Bees of the World. $2^{\text {nd }}$ edn. John Hopkins University Press, Baltimore, 953 pp.

Minh BQ, Schmidt HA, Chernomor O, Schrempf D, Woodhams MD, von Haeseler A, Lanfear R (2020) IQ-TREE 2: New models and efficient methods for phylogenetic inference in the 
genomic era. Molecular Biology and Evolution 37: 1530-1534. https://doi.org/10.1093/ molbev/msaa015

Müller A, Kuhlmann M (2008) Pollen hosts of western palaearctic bees of the genus Colletes (Hymenoptera: Colletidae): the Asteraceae paradox. Biological Journal of the Linnean Society 95: 719-733. https://doi.org/10.1111/j.1095-8312.2008.01113.x

Münster-Swendsen M (1970) The nesting behaviour of the bee Panurgus banksianus Kirby (Hymenoptera, Andrenidae, Panurginae). Insect Systematics \& Evolution 1: 93-101. https:// doi.org/10.1163/187631270X00113

Patiny S (1999a) Etude phylogénétique des Panurginae de l'ancien monde (Hymenoptera, Andrenidae). Linzer biologische Beiträge 31: 249-275.

Patiny S (1999b) Description d'une nouvelle espece de Flavipanurgus Warncke, 1972. Notes fauniques de Gembloux 37: 57-61.

Patiny S (1999c) Révision des Panurginae ouest-paléarctiques n'appartenant pas à la tribu des Melitturgini Michener, 1944, Partie I: Panurgus Panzer, 1806 et Camptopoeum Spinola, 1843. Entomofauna 20: 309-328.

Patiny S (2001) Monographie des Panurginae de l'ancien monde (Hymenoptera: Apoidea, Andrenidae). PhD thesis, Faculté universitaire des sciences agronomiques de Gembloux, Belgium, 278 pp.

Patiny S (2002) Nouvelles espèces de Panurginae (Hymenoptera, Apoidea, Andreninae) du sud de l'Ouest-Paléarctique. Notes fauniques de Gembloux 47: 41-46.

Patiny S, Gaspar C (2000) Premier aperçu de la biodiversité des Panurginae (Hym.: Andrenidae) de l'Anti-Atlas (Maroc). Notes fauniques de Gembloux 41: 33-41.

Pisanty G, Richter R, Martin T, Dettman J, Cardinal S (2021) Molecular phylogeny, historical biogeography and revised classification of andrenine bees (Hymenoptera: Andrenidae). Molecular Phylogenetics and Evolution in press. https://doi.org/10.1016/j.ympev.2021.107151

Portman ZM, Tepedino V (2017) Convergent evolution of pollen transport mode in two distantly related bee genera (Hymenoptera: Andrenidae and Melittidae). Apidologie 48: 461-472. https://doi.org/10.1007/s13592-016-0489-8

Rasmont P, Devalez J, Pauly A, Michez D, Radchenko VG (2017) Addition to the checklist of IUCN European wild bees (Hymenoptera: Apoidea). Annales de la Société entomologique de France 53: 17-32. https://doi.org/10.1080/00379271.2017.1307696

Rozen JG (1971) Biology and immature stages of Moroccan panurgine bees (Hymenoptera, Apoidea). American Museum Novitates 2457: 1-37.

Rozen JG, Wyman ES (2015) The Chilean bees Xeromelissa nortina and X. sielfeldi: their nesting biologies and immature stages, including biological notes on $X$. rozeni (Colletidae: Xeromelissinae). American Museum Novitates 3838: 1-20. https://doi.org/10.1206/3838.1

Shimizu A, Dohzono I, Nakaji M, Roff DA, Miller DG, Osato S, Yajima T, Niitsu S, Utsugi T, Yoshimura J (2014) Fine-tuned bee-flower coevolutionary state hidden within multiple pollination interactions. Scientific Reports 4: e3988. https://doi.org/10.1038/srep03988

Tkalců B (1984) Neue paläarktische Arten der Gattungen Pseudoheriades und Archeriades mit Beschreibung von Hofferia gen. n. (Hymenoptera, Apoidea, Megachilidae). Annotationes Zoologicae et Botanicae 158: 1-22. 
Warncke K (1972) Westpaläarktische Bienen der Unterfamilie Panurginae (Hym., Apidae). Polskie Pismo Entomolgiczne 52: 53-108.

Westrich P (1989) Die Wildbienen Baden-Württembergs. Eugen Ulmer, Germany, 972 pp.

Wood TJ, Cross I (2017) Camptopoeum (Camptopoeum) baldocki spec. nov., a new panurgine bee species from Portugal and a description of the male of Flavipanurgus fuzetus Patiny (Andrenidae: Panurginae). Zootaxa 4254: 285-293. https://doi.org/10.11646/zootaxa.4254.2.9

Wood TJ, Roberts SPM (2018) Constrained patterns of pollen use in Nearctic Andrena (Hymenoptera: Andrenidae) compared with their Palaearctic counterparts. Biological Journal of the Linnean Society 124: 732-746. https://doi.org/10.1093/biolinnean/bly080 